\section{(A) Check for updates}

Cite this: Dalton Trans., 2018, 47 2422

\title{
Synthesis, isomerisation and biological properties of mononuclear ruthenium complexes containing the bis[4(4'-methyl-2,2'-bipyridyl)]-1,7-heptane ligand $\dagger$
}

\author{
Biyun Sun, ${ }^{a}$ Hannah M. Southam, ${ }^{\mathrm{b}}$ Jonathan A. Butler, t $^{\mathrm{b}}$ Robert K. Poole, ${ }^{\mathrm{b}}$ \\ Alexandre Burgun, ${ }^{c}$ Andrew Tarzia, ${ }^{c}$ F. Richard Keene (D) $* c, d$ and J. Grant Collins (D) *a
}

A series of mononuclear ruthenium(॥) complexes containing the tetradentate ligand bis[4(4'-methyl-2,2'bipyridyl)]-1,7-heptane have been synthesised and their biological properties examined. In the synthesis of the $\left[\mathrm{Ru}\left(\mathrm{phen}^{\prime}\right)\left(\mathrm{bb}_{7}\right)\right]^{2+}$ complexes (where phen' = 1,10-phenanthroline and its 5-nitro-, 4,7-dimethyland 3,4,7,8-tetramethyl- derivatives), both the symmetric cis- $\alpha$ and non-symmetric cis- $\beta$ isomers were formed. However, upon standing for a number of days (or more quickly under harsh conditions) the cis- $\beta$ isomer converted to the more thermodynamically stable cis- $\alpha$ isomer. The minimum inhibitory concentrations (MIC) and the minimum bactericidal concentrations (MBC) of the ruthenium(॥) complexes were determined against six strains of bacteria: Gram-positive Staphylococcus aureus (S. aureus) and methicillin-resistant S. aureus (MRSA); and the Gram-negative Escherichia coli (E. coli) strains MG1655, APEC, UPEC and Pseudomonas aeruginosa (P. aeruginosa). The results showed that the $\left[\mathrm{Ru}\left(5-\mathrm{NO}_{2} \mathrm{phen}\right)-\right.$ $\left.\left(b_{7}\right)\right]^{2+}$ complex had little or no activity against any of the bacterial strains. By contrast, for the other cis$\alpha-\left[R u\left(\text { phen }^{\prime}\right)\left(b_{7}\right)\right]^{2+}$ complexes, the antimicrobial activity increased with the degree of methylation. In particular, the cis- $\alpha-\left[\mathrm{Ru}\left(\mathrm{Me}_{4} \text { phen) }\left(\mathrm{bb}_{7}\right)\right]^{2+}\right.$ complex showed excellent and uniform MIC activity against all bacteria. By contrast, the MBC values for the cis- $\alpha-\left[R u\left(M_{4}{ }_{4} p h e n\right)\left(b_{7}\right)\right]^{2+}$ complex varied considerably across the bacteria and even within $S$. aureus and $E$. coli strains. In order to gain an understanding of the relative antimicrobial activities, the DNA-binding affinity, cellular accumulation and water-octanol partition coefficients $(\log P)$ of the ruthenium complexes were determined. Interestingly, all the $\left[R u\left(p h e n^{\prime}\right)\right.$ $\left.\left(b_{7}\right)\right]^{2+}$ complexes exhibited stronger DNA binding affinity $\left(K_{\mathrm{a}} \approx 1 \times 10^{7} \mathrm{M}^{-1}\right)$ than the well-known DNAintercalating complex $\left[R u(p h e n)_{2}(d p p z)\right]^{2+}$ (where dppz = dipyrido[3,2-a:2', $\left.3^{\prime}-c\right]$ phenazine).

Received 6th December 2017, Accepted 12th January 2018 DOI: $10.1039 / \mathrm{c} 7 \mathrm{dt} 04595 f$ rsc.li/dalton

\footnotetext{
${ }^{a}$ School of Physical, Environmental and Mathematical Sciences, University of New South Wales, Australian Defence Force Academy, Canberra, ACT 2600, Australia. E-mail: g.collins@adfa.edu.au

${ }^{b}$ Department of Molecular Biology and Biotechnology, The University of Sheffield, Sheffield, S10 2TN, UK

${ }^{c}$ School of Physical Sciences, University of Adelaide, Adelaide, SA 5005, Australia. E-mail: richard.keene@adelaide.edu.au

${ }^{d}$ Australian Institute of Tropical Health \& Medicine/Centre for Biodiscovery \& Molecular Development of Therapeutics, James Cook University, Townsville, QLD 4811, Australia

$\dagger$ Electronic supplementary information (ESI) available. CCDC 1559396 and 1558934. For ESI and crystallographic data in CIF or other electronic format see DOI: $10.1039 / \mathrm{c} 7 \mathrm{dt} 04595 \mathrm{f}$

\$Current Address: School of Healthcare Science, Manchester Metropolitan University, Manchester M1, 5GD, UK.
}

\section{Introduction}

Due to a developing resistance to antimicrobial drugs, bacterial diseases are becoming a significantly greater threat to humans. Of note, the World Health Organisation has stated that antimicrobial resistance is one of the most important problems currently affecting global health, food security and development. ${ }^{1}$ As a consequence, there is considerable interest in the development of new classes of antimicrobial agents, and while the development of new drugs based upon organic compounds continues, transition metal-based antimicrobial agents in general have been attracting attention - and ruthenium(II) complexes in particular. ${ }^{2-14} \mathrm{~A}$ range of ruthenium(II) complexes have been studied, and generally have shown good activity against Gram-positive bacteria, but variable and often poor activity against Gram-negative species. ${ }^{10-12}$

Dwyer and co-workers were the first to study the biological activity of mononuclear tris(bidentate) inert metal complexes 
with ligands such as 1,10-phenanthroline (phen) and its derivatives $\quad\{$ e.g. $\quad 3,4,7,8$-tetramethyl-1,10-phenanthroline ( $\mathrm{Me}_{4}$ phen) and 5-nitro-1,10-phenanthroline (5- $\mathrm{NO}_{2}$ phen) $\} .{ }^{9}$ More recently, a wide range of mononuclear $\{$ e.g. $[\mathrm{Ru}(2,9-$ $\mathrm{Me}_{2}$ phen $\left.\left.)_{2}(\mathrm{dppz})\right]^{2+}\right\}$ (2,9-Me ${ }_{2}$ phen = 2,9-dimethyl-1,10-phenanthroline; dppz $=$ dipyrido $\left[3,2-a: 2^{\prime}, 3^{\prime}-c\right]$ phenazine $)^{10}$ and diand oligo-nuclear polypyridylruthenium(II) ${ }^{12,14,15}$ complexes have been examined. In particular, earlier studies from our laboratories have examined the antimicrobial properties of di-, triand tetra-nuclear polypyridylruthenium(II) complexes in which the metal centres are linked by the bis[4(4'-methyl-2,2'-bipyridyl)]-1,n-alkane ligand ("bb ${ }_{n}$ "; see Fig. 1). ${ }^{14}$ While these oligonuclear ruthenium complexes showed excellent activity against drug-sensitive Gram-positive bacterial strains, and maintained the activity against drug-resistant strains, they exhibited relatively poor activity against some Gram-negative strains. ${ }^{16}$ More recently, we synthesised mononuclear ruthenium complexes that contained the $\mathrm{bb}_{n}$ moiety (for $n=10$ and 12), but as a tetradentate ligand, ${ }^{17}$ rather than as a ligand linking metal centres. While the $c i s-\alpha-\left[\mathrm{Ru}(\text { phen })\left(\mathrm{bb}_{12}\right)\right]^{2+}$ species showed better activity towards the clinically-important Gram-negative Pseudomonas aeruginosa, its activity against other bacteria was only equivalent to $\left[\mathrm{Ru}\left(\mathrm{Me}_{4} \text { phen }\right)_{3}\right]^{2+8}$ the most active of the ruthenium complexes prepared by Dwyer and co-workers sixty years ago. The cis- $\alpha-\left[\mathrm{Ru}(\mathrm{phen})\left(\mathrm{bb}_{10}\right)\right]^{2+}$ complex was less active than cis- $\alpha-[\mathrm{Ru}-$ (phen) $\left.\left(\mathrm{bb}_{12}\right)\right]^{2+}$ and $\left[\mathrm{Ru}\left(\mathrm{Me}_{4} \text { phen }\right)_{3}\right]^{2+}$ against most of the bacterial strains. ${ }^{17}$ The antimicrobial activity of the $[\mathrm{Ru}(\mathrm{phen})-$ $\left.\left(\mathrm{bb}_{n}\right)\right]^{2+}$ complexes could be potentially improved through an increase of the lipophilicity, for example by utilising the $b_{16}$ ligand. However, an alternative approach is to decrease the lipophilicity of the $\mathrm{bb}_{n}$ chain but increase the electron density at the ruthenium centre through the incorporation of electrondonating groups on the 1,10-phenanthroline ligand. It has been established that the antimicrobial activity of the metal complexes is significantly affected by the cellular uptake, ${ }^{15}$ which in turn is presumably sensitive to the charge on the metal centre as well as the overall lipophilicity. Consequently, the modulation of the electron density at the metal centre could provide higher uptake and greater ability to modulate the differential uptake between bacterial and eukaryotic cells.

Herein, we describe the synthesis of a series of complexes involving 1,10-phenanthroline and some of its deriva-

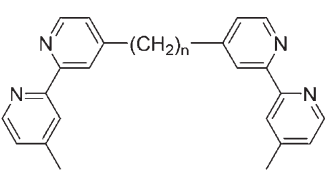

$\mathbf{b b}_{\mathrm{n}}$

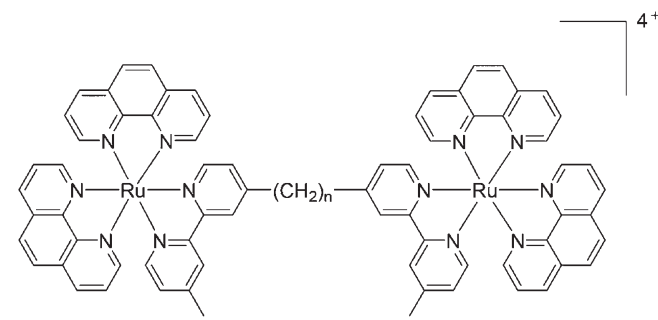

$\mathrm{Rubb}_{\mathrm{n}}$

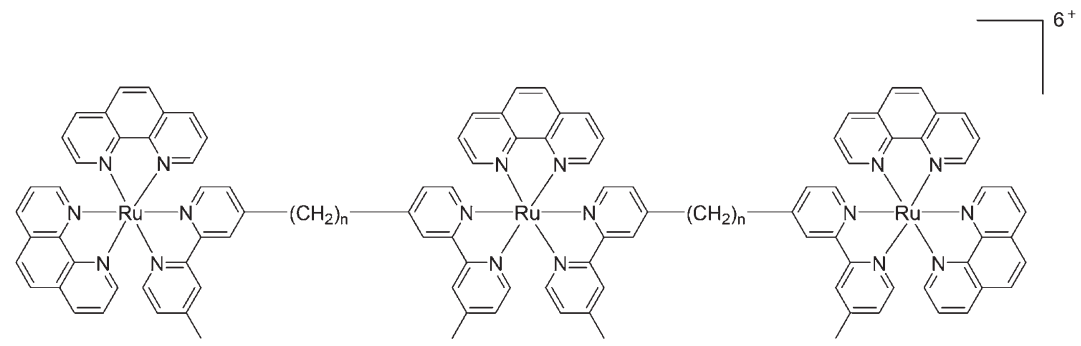

Rubb $_{n}$-tri

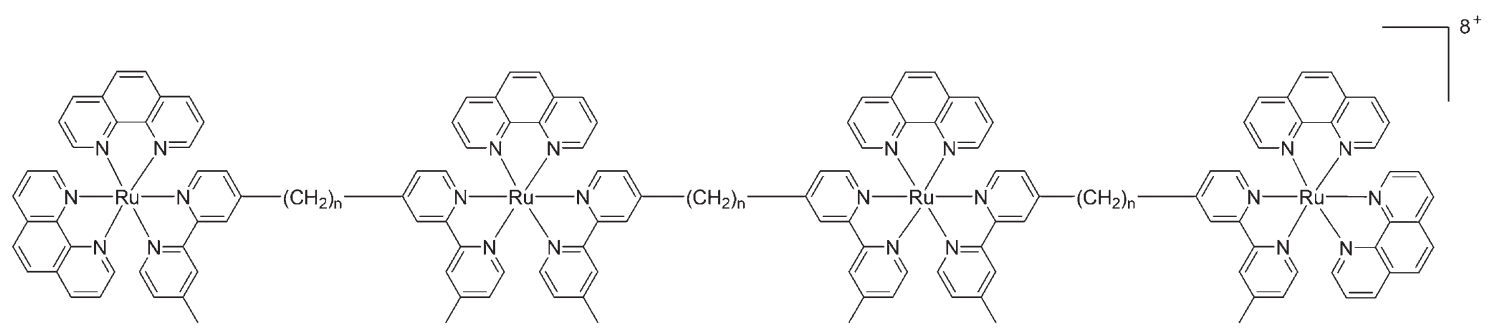

Rubb $_{\mathrm{n}}$-tetra

Fig. 1 The $\mathrm{bb}_{n}$ ligand and the Rubb ${ }_{n}, \mathrm{Rubb}_{n}$-tri and Rubb ${ }_{n}$-tetra complexes. 
tives - $\left[\mathrm{Ru}\left(\mathrm{phen}^{\prime}\right)\left(\mathrm{bb}_{7}\right)\right]^{2+}$ \{where phen' $=$ phen; 4,7-dimethyl1,10-phenanthroline ( $\mathrm{Me}_{2}$ phen); $\mathrm{Me}_{4}$ phen; and 5- $\mathrm{NO}_{2}$ phen\} and an examination of their DNA binding, cellular uptake and antimicrobial activity against a range of bacteria. Synthetically, the results indicate that although the cis- $\beta-\left[\mathrm{Ru}\left(\mathrm{phen}^{\prime}\right)\left(\mathrm{bb}_{7}\right)\right]^{2+}$ complexes are formed initially they are unstable and are converted to the cis- $\alpha$ isomer and, to a very small extent, the corresponding $\left[\mathrm{Ru}\left(\mathrm{phen}^{\prime}\right)\left(\mathrm{Me}_{2} \mathrm{bpy}\right)_{2}\right]^{2+}$ species. The $c i s-\alpha-\left[\mathrm{Ru}\left(\mathrm{Me}_{4} \mathrm{phen}\right)\right.$ $\left.\left(b_{7}\right)\right]^{2+}$ complex showed uniformly high activity against Grampositive and Gram-negative bacteria. Furthermore, the results demonstrate the effect of the electron density at the ruthenium centre on the cellular uptake of the metal complexes.

\section{Results}

\section{Synthesis of cis- $\alpha-\left[\operatorname{Ru}\left(\mathrm{phen}^{\prime}\right)\left(\mathrm{bb}_{7}\right)\right]^{2+}$ complexes}

The synthesis of the cis- $\alpha$ and cis- $\beta$ isomers of $[\mathrm{Ru}(\mathrm{phen})$ $\left.\left(b_{12}\right)\right]^{2+}$ was carried out as previously reported. ${ }^{17}$

The synthesis of a series of mononuclear $c i s-\alpha-\left[\mathrm{Ru}\left(\right.\right.$ phen' $\left.^{\prime}\right)-$ $\left.\left(\mathrm{bb}_{7}\right)\right]^{2+}$ complexes was achieved with good yields, as shown in Scheme 1 , by heating cis,cis-[ $\left[\mathrm{RuCl}_{2}(\mathrm{DMSO})_{2}\left(\mathrm{phen}^{\prime}\right)\right]^{17}$ to $130-140{ }^{\circ} \mathrm{C}$ with the $\mathrm{bb}_{7}$ ligand in ethylene glycol: the $2+$ complexes were isolated from higher-charged species using cationexchange chromatography on a SP Sephadex C-25 column with aqueous sodium chloride as the eluent, and the resulting solid products recrystallised from acetonitrile/diethyl ether. Subsequent cation-exchange chromatography on a SP Sephadex C-25 column (1 metre) with sodium toluene-4-sulfonate as the eluent realised two bands - the cis- $\alpha$ isomer and corresponding $\left[\mathrm{Ru}\left(\text { phen' }^{\prime}\right)\left(\mathrm{Me}_{2} \mathrm{bpy}\right)_{2}\right]^{2+}$ species as a minor product. All the complexes were characterised by microanalysis, NMR spectroscopy and high-resolution electrospray ionisation (ESI) mass spectrometry. The cis- $\alpha-\left[\mathrm{Ru}\left(\mathrm{Me}_{4} \text { phen }\right)\left(\mathrm{bb}_{7}\right)\right]^{2+}$ complex was also characterised by X-ray crystallography (see Table 1 and Fig. 2).

In our recent synthetic study ${ }^{17}$ of the analogous $[\mathrm{Ru}(\mathrm{phen})$ $\left.\left(\mathrm{bb}_{10}\right)\right]^{2+}$ and $\left[\mathrm{Ru}(\mathrm{phen})\left(\mathrm{bb}_{12}\right)\right]^{2+}$ complexes, in both cases the $c i s-\alpha$ isomers and cis- $\beta$ isomers (see Fig. 3 ) were isolated and individually characterised. In the present case, only the cis$\alpha-\left[\mathrm{Ru}\left(\mathrm{phen}^{\prime}\right)\left(\mathrm{bb}_{7}\right)\right]^{2+}$ isomer was isolated, and consequently the cis,cis-[ $\mathrm{RuCl}_{2}(\mathrm{DMSO})_{2}\left(\mathrm{Me}_{4}\right.$ phen)] reaction with the $\mathrm{bb}_{7}$ ligand was examined in detail. When samples were taken from the reaction mixture during the course of the synthesis and studied by ${ }^{1} \mathrm{H}$ NMR, both the cis- $\alpha$ and cis- $\beta$ isomers were unambiguously identified in COSY spectra of the reaction mixture. However, after either heating the reaction mixture to $200{ }^{\circ} \mathrm{C}$ (see Fig. 4) or allowing the mixture of the isolated isomers stand at room temperature for several weeks, only the cis- $\alpha$ isomer was observed. In addition, during the purification process for the cis- $\alpha$ isomer for all the $\left[\mathrm{Ru}\left(\mathrm{phen}^{\prime}\right)\left(\mathrm{bb}_{7}\right)\right]^{2+}$ cases, a small amount $(<5 \%$ yield based upon starting material) of $\left[\mathrm{Ru}\left(\text { phen }^{\prime}\right)\left(\mathrm{Me}_{2} \mathrm{bpy}\right)_{2}\right]^{2+}$ was observed: for phen' $=\mathrm{Me}_{2}$ phen and $\mathrm{Me}_{4}$ phen, the products were isolated and the ${ }^{1} \mathrm{H}$ NMR and TOF-MS (ESI + ) characterisation data are provided in the ESI. $\dagger$ For $\left[\mathrm{Ru}\left(\mathrm{Me}_{4} \mathrm{phen}\right)\left(\mathrm{Me}_{2} \mathrm{bpy}\right)_{2}\right]^{2+}$, the structure confirmed by X-ray crystallography (see Fig. S1: ESI $\dagger$ ).

The same observations were made for reactions conducted under normal laboratory light or in the dark.

As the $c i s-\beta-\left[\mathrm{Ru}\left(\mathrm{Me}_{4} \mathrm{phen}\right)\left(\mathrm{bb}_{7}\right)\right]^{2+}$ complex appeared to be less stable than the corresponding cis- $\alpha$ isomer, it was of interest to compare the relative energies of the isomers through DFT calculations. In addition, the differences in energies between the $c i s-\alpha$ and $c i s-\beta$ isomers for the $\mathrm{bb}_{7}$ complex were compared to those for the corresponding $b_{12}$ complex. As shown in Table 2, there was good agreement between the X-ray and DFT-optimised structures based upon the cis- $\alpha-[\mathrm{Ru}-$ $\left(\mathrm{Me}_{4}\right.$ phen $\left.)\left(\mathrm{bb}_{7}\right)\right]^{2+} \mathrm{N}-\mathrm{Ru}-\mathrm{N}$ angles for the corresponding chelate rings. While there were only small differences in the $\mathrm{N}-\mathrm{Ru}-\mathrm{N}$ bond angles between the cis- $\alpha-\left[\mathrm{Ru}\left(\mathrm{Me}_{4} \text { phen }\right)\left(\mathrm{bb}_{7}\right)\right]^{2+}$ (designated $\alpha-\mathrm{Me}_{4}$ phen-7) and the $c i s-\alpha-\left[\mathrm{Ru}\left(\mathrm{Me}_{4} \text { phen }\right)\left(\mathrm{bb}_{12}\right)\right]^{2+}$ (designated $\alpha-\mathrm{Me}_{4}$ phen-12) complexes, significant differences were observed between the corresponding cis- $\beta$ isomers (designated $\beta-\mathrm{Me}_{4}$ phen-7 and $\beta-\mathrm{Me}_{4}$ phen-12, respectively): see Table 3. Furthermore, the $\beta-\mathrm{Me}_{4}$ phen- 12 complex was determined to be $5.6 \mathrm{~kJ} \mathrm{~mol}^{-1}$ less stable than the $\alpha-\mathrm{Me}_{4}$ phen-12, whereas by contrast $\beta-\mathrm{Me}_{4}$ phen-7 was $76.8 \mathrm{~kJ} \mathrm{~mol}^{-1}$ less stable than the $\alpha-\mathrm{Me}_{4}$ phen-7 isomer. It is observed that the calculated difference in the N1-Ru-N5 angle between the $\beta-\mathrm{Me}_{4}$ phen-7 and $\beta-\mathrm{Me}_{4}$ phen-12 species is significant (Table 3 ), and this may well be the origin of the instability of the $\beta-\mathrm{Me}_{4}$ phen-7 species relative to both the $\alpha-\mathrm{Me}_{4}$ phen- 7 isomer and the $\beta-\mathrm{Me}_{4}$ phen-12 analogue. However, no significant differences in the calculated $\mathrm{Ru}-\mathrm{N}$ bond lengths were observed between the $\alpha-\mathrm{Me}_{4}$ phen-7 and $\beta-\mathrm{Me}_{4}$ phen-7 isomers.

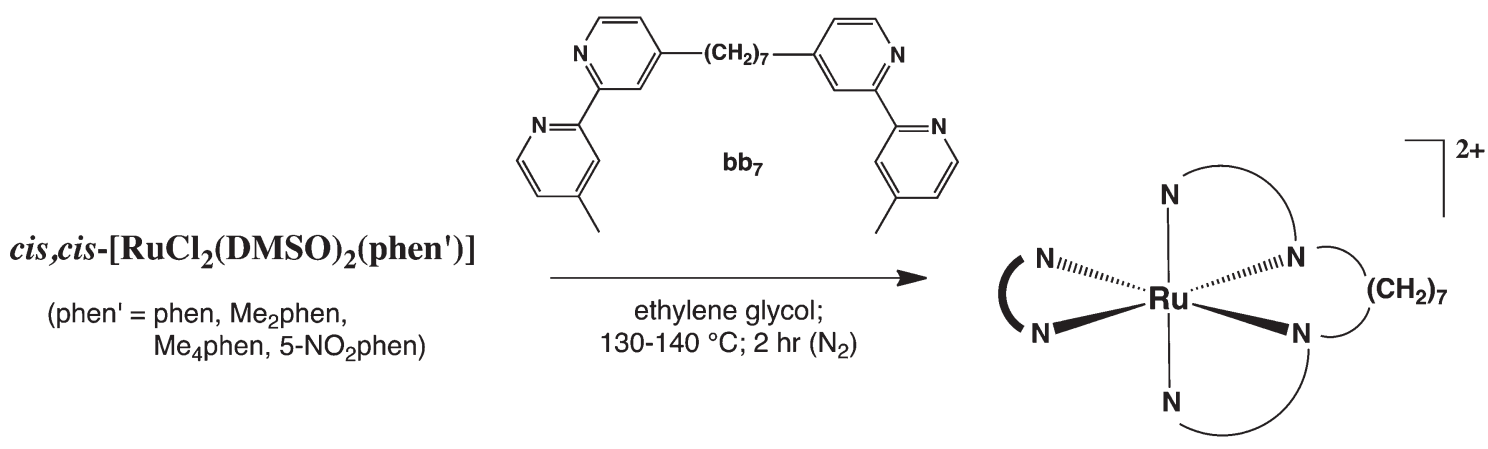

Scheme 1 Synthesis of $\left[R u\left(p h e n^{\prime}\right)\left(b_{7}\right)\right]^{2+}$ complexes containing the $\mathrm{bb}_{7}$ ligand. 
Table 1 X-Ray experimental and refinement data for cis- $\alpha-\left[R u\left(M e_{4} \text { phen }\right)\left(b_{7}\right)\right]^{2+}$ and $\left[R u\left(M e_{4} \text { phen }\right)\left(M e_{2} b p y\right)\right]^{2+}$

\begin{tabular}{|c|c|c|}
\hline Compound & cis- $\alpha-\left[\mathrm{Ru}\left(\mathrm{Me}_{4}\right.\right.$ phen $\left.)\left(\mathrm{bb}_{7}\right)\right]\left(\mathrm{PF}_{6}\right)_{2} \cdot 3\left(\mathrm{CHCl}_{3}\right)($ Fig. 2$)$ & {$\left[\mathrm{Ru}\left(\mathrm{Me}_{4}\right.\right.$ phen $\left.)\left(\mathrm{Me}_{2} \mathrm{bpy}\right)\right]\left(\mathrm{PF}_{6}\right)_{2} \cdot 0.25\left(\mathrm{H}_{2} \mathrm{O}\right)$ (Fig. S1; ESI) } \\
\hline Empirical formula & $\mathrm{C}_{48} \mathrm{H}_{51} \mathrm{Cl}_{9} \mathrm{~F}_{12} \mathrm{~N}_{6} \mathrm{P}_{2} \mathrm{Ru}$ & $\mathrm{C}_{40} \mathrm{H}_{40.5} \mathrm{~F}_{12} \mathrm{~N}_{6} \mathrm{O}_{0.25} \mathrm{P}_{2} \mathrm{Ru}$ \\
\hline Formula weight & 1422.01 & 1000.29 \\
\hline Crystal system & Monoclinic & Monoclinic \\
\hline Space group & $P 2_{1} / c$ & $P 2_{1} / c$ \\
\hline$a(\AA)$ & $9.853(2)$ & $10.782(2)$ \\
\hline$b(\AA)$ & $28.124(6)$ & $28.514(6)$ \\
\hline$c(\AA)$ & $20.632(4)$ & $13.176(3)$ \\
\hline \multicolumn{3}{|l|}{$\alpha(0)$} \\
\hline$\beta\left({ }^{\circ}\right)$ & $92.25(3)$ & $96.63(3)$ \\
\hline \multicolumn{3}{|l|}{$\gamma\left(0^{\circ}\right)$} \\
\hline Volume $\left(\AA^{3}\right)$ & $5713(2)$ & $4023.7(14)$ \\
\hline$Z$ & 4 & 4 \\
\hline Density (calc.) $\mathrm{g} \mathrm{m}^{-3}$ & 1.653 & 1.651 \\
\hline Absorption coefficient $\left(\mathrm{mm}^{-1}\right)$ & 0.832 & 0.566 \\
\hline$F(000)$ & 2864 & 2026 \\
\hline Crystal size $\left(\mathrm{mm}^{3}\right)$ & $0.567 \times 0.100 \times 0.017$ & $0.289 \times 0.255 \times 0.006$ \\
\hline$\theta$ range for collection $\left({ }^{\circ}\right)$ & 1.225 to 31.928 & 1.428 to 31.900 \\
\hline Reflections collected & 105036 & 75249 \\
\hline Observed reflections $[R$ (int $)]$ & $14330[0.0463]$ & $11496[0.0794]$ \\
\hline Goodness-of-fit on $F_{2}$ & 1.049 & 1.036 \\
\hline$R_{1}[I>2 \sigma(I)]$ & 0.0488 & 0.0489 \\
\hline $\mathrm{w} R_{2}$ (all data) & 0.1349 & 0.1272 \\
\hline Largest diff. peak and hole $\left(\mathrm{e} \AA^{-3}\right)$ & $1.553,-2.055$ & $0.535,-1.420$ \\
\hline
\end{tabular}

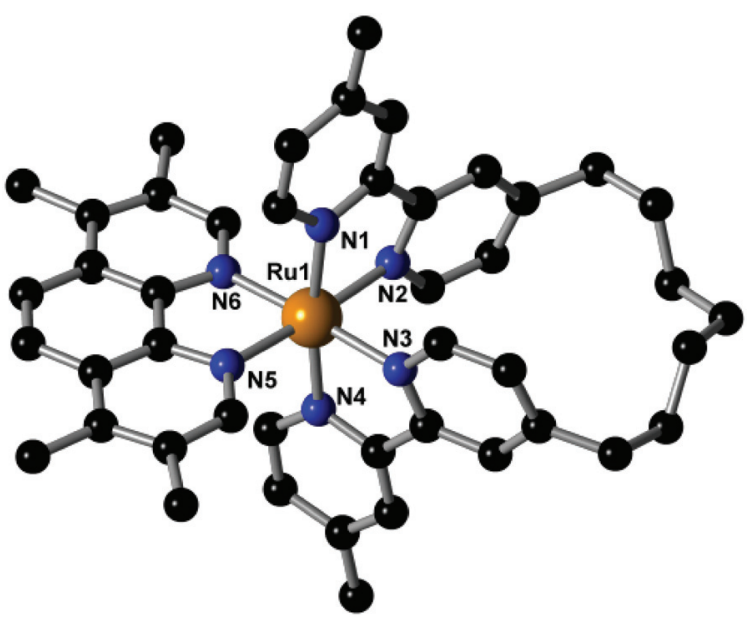

Fig. 2 X-ray crystal structure of the cis- $\alpha-\left[R u\left(M e_{4} \text { phen }\right)\left(b_{7}\right)\right]^{2+}$ complex.

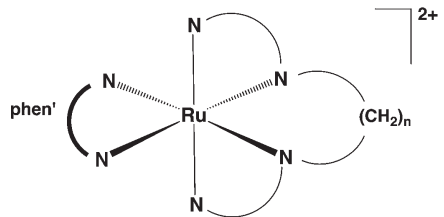

cis- $\alpha$

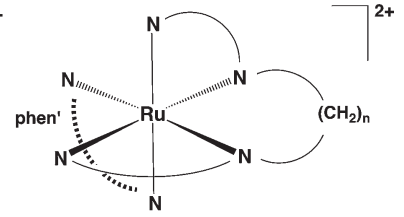

cis- $\beta$
Fig. 3 Structures of $c i s-\alpha-$ and $c i s-\beta-\left[R u\left(\text { phen }^{\prime}\right)\left(b_{n}\right)\right]^{2+}$.

\section{Antimicrobial activity}

The minimum inhibitory concentrations (MIC) for the ruthenium complexes against six bacterial strains (methicillin-resistant Staphylococcus aureus (MRSA) and a methicillin-sensitive strain of $S$. aureus, both avian pathogenic (APEC) and uropathogenic (UPEC) strains of Escherichia coli as well as a laboratory strain (E. coli MG1655), and Pseudomonas aeruginosa PAO1) were determined and the results are summarised in Table 4. Interestingly, the $\left[\mathrm{Ru}\left(5-\mathrm{NO}_{2} \text { phen }\right)\left(\mathrm{bb}_{7}\right)\right]^{2+}$ complex (designated $\alpha-\mathrm{NO}_{2}$ phen-7) showed very little or no activity against any of the bacterial strains. By contrast, for the other cis- $\alpha-\left[\mathrm{Ru}\left(\mathrm{phen}^{\prime}\right)\left(\mathrm{bb}_{7}\right)\right]^{2+}$ complexes, the antimicrobial activities increased with the degree of methylation. Most importantly, cis- $\alpha-\left[\mathrm{Ru}\left(\mathrm{Me}_{4} \text { phen }\right)\left(\mathrm{bb}_{7}\right)\right]^{2+}$ displayed very similar activity against all bacterial strains: for ruthenium(II)-based complexes, the observed similarity in activity against Grampositive and Gram-negative is rare. In absolute terms, the cis$\alpha-\left[\mathrm{Ru}\left(\mathrm{Me}_{4} \text { phen }\right)\left(\mathrm{bb}_{7}\right)\right]^{2+}$ complex exhibited comparable or better activities to the Gram-negative species compared to cis$\alpha-\left[\mathrm{Ru}\left(\mathrm{Me}_{4} \text { phen }\right)\left(\mathrm{bb}_{12}\right)\right]^{2+}$ and $\left[\mathrm{Ru}\left(\mathrm{Me}_{4} \text { phen }\right)_{3}\right]^{2+}$ \{designated $\left(\mathrm{Me}_{4}\right.$ phen) $\left.{ }_{3}\right\}$. The dinuclear complexes Rubb ${ }_{7}$ and $\mathrm{Rubb}_{12}$ (see Fig. 1) were also examined, and the results indicated that the cis- $\alpha-\left[\mathrm{Ru}\left(\mathrm{Me}_{4} \text { phen }\right)\left(\mathrm{bb}_{7}\right)\right]^{2+}$ complex was more active than $\mathrm{Rubb}_{7}$, but less active than Rubb ${ }_{12}$.

The minimum bactericidal concentrations (MBC) of the ruthenium complexes were also determined, and the results are summarised in Table 5. Consistent with previous results, the $\mathrm{MBC}$ values for $\mathrm{Rubb}_{12}$ and $\left[\mathrm{Ru}\left(\mathrm{Me}_{4} \text { phen }\right)_{3}\right]^{2+}$ were generally $\leq 2 \times$ MIC, indicating that the two ruthenium complexes are bactericidal. By contrast, $c i s-\alpha-\left[\mathrm{Ru}(\text { phen })\left(\mathrm{bb}_{12}\right)\right]^{2+}$ is borderline bactericidal/bacteriostatic. Surprisingly, the MBC values for $c i s-\alpha-\left[\mathrm{Ru}\left(\mathrm{Me}_{4} \mathrm{phen}\right)\left(\mathrm{bb}_{7}\right)\right]^{2+}$ show considerable variation, e.g. $S$. aureus compared to MRSA, or APEC to UPEC. Based upon the $\mathrm{MBC} / \mathrm{MIC}$ ratios, cis- $\alpha-\left[\mathrm{Ru}\left(\mathrm{Me}_{4} \text { phen }\right)\left(\mathrm{bb}_{7}\right)\right]^{2+}$ is clearly bactericidal against MRSA and APEC, but bacteriostatic against $S$. aureus and UPEC. These significant differences within both the Gram-positive and Gram-negative classes of bacteria indi- 


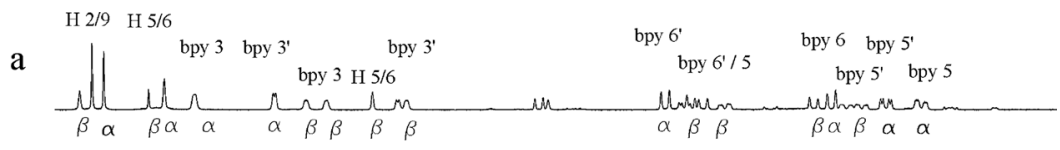

b

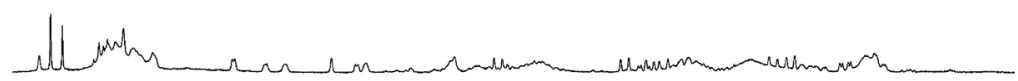

c

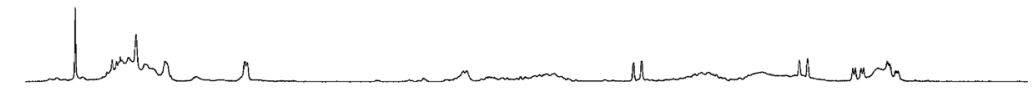

d

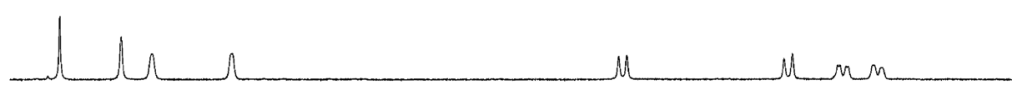

$\mathrm{e}$

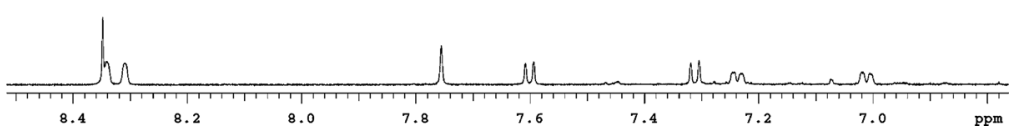

Fig. 4 Aromatic region of the ${ }^{1} \mathrm{H}$ NMR spectra of cis- $\alpha$ and cis- $\beta$ isomers of $\left[R u\left(\mathrm{Me}_{4} \text { phen) }\left(\mathrm{bb}_{7}\right)\right]^{2+}\right.$ and reaction mixtures in $\mathrm{CD}_{3} \mathrm{CN}$ at different reaction conditions. (a) Isolated mixture of the cis- $\alpha$ and cis- $\beta$ isomers (sample from reaction after $2 \mathrm{~h}$ at $130-1400^{\circ} \mathrm{C}$ ). (b) Isolated products from reaction (Scheme 1) after $1 \mathrm{~h}$ at $130-140{ }^{\circ} \mathrm{C}$. (c) Isolated products from reaction (Scheme 1) after $1 \mathrm{~h}$ at $130-140{ }^{\circ} \mathrm{C}$ and then a second hour at $200{ }^{\circ} \mathrm{C}$. (d) $c i s-\alpha-\left[R u\left(M e_{4} \text { phen) }\left(\mathrm{bb}_{7}\right)\right]^{2+}\right.$ and (e) $\left[R u\left(\mathrm{Me}_{4} \text { phen) }\left(\mathrm{Me}_{2} \mathrm{bpy}\right)\right]^{2+}\right.$.

Table 2 Comparison of angles (in degrees) in cis- $\alpha-\left[R u\left(\mathrm{Me}_{4}\right.\right.$ phen) $\left.\left(b_{7}\right)\right]^{2+} X$-ray crystal and DFT-optimised structures. Nomenclature is defined in Fig. 5

\begin{tabular}{lccc}
\hline & $\begin{array}{l}\alpha-\mathrm{Me}_{4} \text { phen-7 } \\
\text { Angle }\end{array}$ & $\begin{array}{l}\alpha-\mathrm{Me}_{4} \text { phen-7 } \\
(\text { crystal structure })\end{array}$ & \% deviation \\
\hline N1-Ru-N2 & 78.9 & 77.5 & 1.77 \\
N1-Ru-N3 & 94.6 & 95.5 & 0.95 \\
N1-Ru-N5 & 97.1 & 97.3 & 0.21 \\
N1-Ru-N6 & 88.9 & 89.5 & 0.67 \\
N4-Ru-N2 & 94.6 & 95.6 & 1.06 \\
N4-Ru-N3 & 78.5 & 77.4 & 1.40 \\
N4-Ru-N5 & 89.4 & 89.9 & 0.56 \\
N4-Ru-N6 & 98.2 & 97.8 & 0.41 \\
N2-Ru-N6 & 100.6 & 99.5 & 1.09 \\
N2-Ru-N3 & 82.1 & 83.7 & 1.95 \\
N3-Ru-N5 & 98.4 & 99.1 & 0.71 \\
N3-Ru-N6 & 176.0 & 174.6 & 0.80
\end{tabular}

cate that cis- $\alpha-\left[\mathrm{Ru}\left(\mathrm{Me}_{4} \text { phen }\right)\left(\mathrm{bb}_{7}\right)\right]^{2+}$ has significant specific toxicity to some bacteria and suggests that the mechanism of the activity is considerably different compared to $\left[\mathrm{Ru}\left(\mathrm{Me}_{4} \text { phen }\right)\left(\mathrm{bb}_{12}\right)\right]^{2+},\left[\mathrm{Ru}\left(\mathrm{Me}_{4} \text { phen }\right)_{3}\right]^{2+}$ and $\mathrm{Rubb}_{12}$.

\section{Lipophilicity $(\log P)$}

Lipophilicity is a factor that affects the biological activity of any metal complex because it is often correlated with the capacity of the drug to penetrate through the cell membrane. The standard octanol/water partition coefficients $(\log P)$ were determined for the $\left[\mathrm{Ru}\left(\mathrm{phen}^{\prime}\right)\left(\mathrm{bb}_{n}\right)\right]^{2+}$ and $\left[\mathrm{Ru}\left(\mathrm{Me}_{4} \text { phen }\right)_{3}\right]^{2+}$ complexes, and the results are summarised in Table 6. As expected, $c i s-\alpha-\left[\mathrm{Ru}\left(\mathrm{Me}_{4} \text { phen }\right)\left(\mathrm{bb}_{7}\right)\right]^{2+}$ was more lipophilic than the other $c i s-\alpha-\left[\mathrm{Ru}\left(\text { phen' }^{\prime}\right)\left(\mathrm{bb}_{7}\right)\right]^{2+}$ analogues. The introduction of the nitro-substituent on 1,10-phenanthroline ligand in cis$\alpha-\left[\mathrm{Ru}\left(5-\mathrm{NO}_{2} \text { phen }\right)\left(\mathrm{bb}_{7}\right)\right]^{2+}$ did not decrease the lipophilicity compared with the $c i s-\alpha-\left[\mathrm{Ru}(\mathrm{phen})\left(\mathrm{bb}_{7}\right)\right]^{2+}$ analogue. More significantly, the cis- $\alpha-\left[\mathrm{Ru}\left(\mathrm{Me}_{4} \mathrm{phen}\right)\left(\mathrm{bb}_{7}\right)\right]^{2+}$ isomer is more lipophilic than the $\mathrm{Rubb}_{n}$ complexes, but of similar lipophilicity to $\left[\mathrm{Ru}\left(\mathrm{Me}_{4} \text { phen }\right)_{3}\right]^{2+}$, and less lipophilic than their $[\mathrm{Ru}(\mathrm{phen})-$ $\left.\left(\mathrm{bb}_{12}\right)\right]^{2+}$ analogues.

\section{Cellular accumulation}

The cellular accumulations of the $c i s-\alpha-\left[\mathrm{Ru}\left(\text { phen' }^{\prime}\right)\left(\mathrm{bb}_{n}\right)\right]^{2+}$ analogues (and $\mathrm{Rubb}_{12}$ and $\left[\mathrm{Ru}\left(\mathrm{Me}_{4} \text { phen) }\right)_{3}\right]^{2+}$ ) in MRSA, UPEC and

Table 3 Comparison of angles (in degrees) in all DFT-optimised structures. Nomenclature is defined in Fig. 5

\begin{tabular}{|c|c|c|c|c|c|}
\hline Angle & $\alpha-\mathrm{Me}_{4}$ phen-7 & $\alpha-\mathrm{Me}_{4}$ phen-12 & $\beta-\mathrm{Me}_{4}$ phen-7 & $\beta-\mathrm{Me}_{4}$ phen-12 & {$\left[\mathrm{Ru}\left(\mathrm{Me}_{2} \mathrm{bpy}\right)_{2}-\left(\mathrm{Me}_{4} \text { phen }\right)\right]^{2+}$} \\
\hline N1-Ru-N2 & 77.5 & 77.3 & 76.9 & 77.4 & 77.2 \\
\hline N1-Ru-N3 & 95.5 & 98.1 & 89.2 & 88.8 & 89.6 \\
\hline N1-Ru-N5 & 97.3 & 96.5 & 103.9 & 99.1 & 97.5 \\
\hline N1-Ru-N6 & 89.5 & 88.4 & 96.5 & 97.2 & 96.4 \\
\hline $\mathrm{N} 4-\mathrm{Ru}-\mathrm{N} 2$ & 95.6 & 98.0 & 96.2 & 96.7 & 97.3 \\
\hline $\mathrm{N} 4-\mathrm{Ru}-\mathrm{N} 3$ & 77.4 & 77.3 & 97.2 & 96.5 & 96.5 \\
\hline N4-Ru-N5 & 89.9 & 88.4 & 84.2 & 87.3 & 88.4 \\
\hline N4-Ru-N6 & 97.8 & 96.4 & 77.6 & 77.9 & 78.0 \\
\hline N2-Ru-N6 & 99.5 & 97.6 & 94.2 & 89.3 & 88.1 \\
\hline $\mathrm{N} 2-\mathrm{Ru}-\mathrm{N} 3$ & 83.7 & 87.3 & 91.0 & 96.6 & 98.2 \\
\hline N3-Ru-N5 & 99.1 & 97.7 & 75.8 & 77.3 & 77.2 \\
\hline N3-Ru-N6 & 174.6 & 172.6 & 173.0 & 172.3 & 172.1 \\
\hline
\end{tabular}


Table 4 MIC values $\left(\mu \mathrm{g} \mathrm{mL}^{-1}\right)$ for the ruthenium complexes after a 16-18 hours incubation against Gram-positive and Gram-negative bacteria

\begin{tabular}{|c|c|c|c|c|c|c|}
\hline \multirow[b]{2}{*}{ Compound } & \multicolumn{2}{|c|}{ Gram-positive } & \multicolumn{4}{|l|}{ Gram-negative } \\
\hline & S. aureus & MRSA & E. coli MG1655 & E. coli APEC & E. coli UPEC & P. aeruginosa $\mathrm{PAO} 1$ \\
\hline$\alpha$-phen-7 & 8 & 16 & $>128$ & $>128$ & $>128$ & $>128$ \\
\hline$\alpha-\mathrm{Me}_{2}$ phen-7 & 8 & 8 & 32 & 64 & 128 & $>128$ \\
\hline$\alpha-\mathrm{Me}_{4}$ phen-7 & 4 & 4 & 4 & 8 & 8 & 8 \\
\hline$\alpha-\mathrm{NO}_{2}$ phen-7 & 128 & 128 & $>128$ & $>128$ & $>128$ & $>128$ \\
\hline$\alpha$-phen-12 & $1-2$ & 2 & 4 & 8 & 8 & 16 \\
\hline$\beta$-phen-12 & 2 & 2 & 8 & 16 & 16 & 32 \\
\hline$\left(\mathrm{Me}_{4} \text { phen }\right)_{3}$ & $0.5-1$ & 0.5 & 4 & 4 & 8 & 32 \\
\hline $\mathrm{Rubb}_{7}$ & 8 & 8 & 16 & 4 & 16 & 128 \\
\hline Rubb $_{12}$ & 2 & 2 & 2 & 2 & 2 & 16 \\
\hline Gentamicin & 0.25 & 0.25 & 0.5 & 0.5 & 1 & 0.25 \\
\hline
\end{tabular}

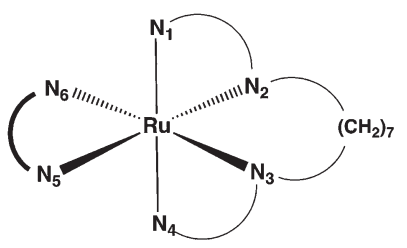

$\alpha-\mathrm{Me}_{4}$ phen-7

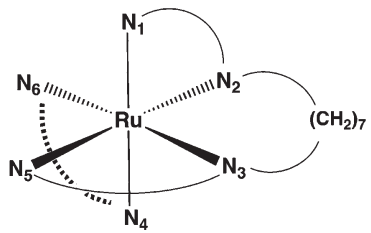

$\beta-\mathrm{Me}_{4}$ phen-7

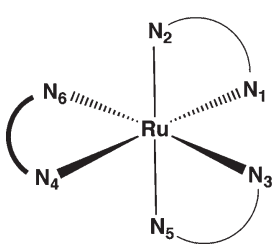

$\left[\mathrm{Ru}\left(\mathrm{Me}_{2} \mathrm{bpy}\right)_{2}\left(\mathrm{Me}_{4} \mathrm{phen}\right)\right]^{2+}$

Fig. 5 Atom label nomenclature for the ruthenium complexes in this work, shown for $\left[R u\left(p h e n^{\prime}\right)\left(b_{n}\right)\right]^{2+}\left\{\right.$ where phen' $^{\prime}=M_{4}$ phen $(\mathrm{shown}$ bolded);

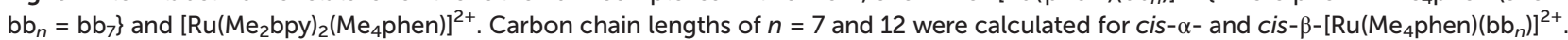

Table $5 \mathrm{MBC}$ values $\left(\mu \mathrm{g} \mathrm{mL} \mathrm{L}^{-1}\right.$ ) for the ruthenium complexes against Gram-positive and Gram-negative bacterial strains

\begin{tabular}{|c|c|c|c|c|c|c|}
\hline \multirow[b]{2}{*}{ Compound } & \multicolumn{2}{|c|}{ Gram-positive } & \multicolumn{4}{|c|}{ Gram-negative } \\
\hline & S. aureus & MRSA & MG1655 & APEC & UPEC & PAO1 \\
\hline$\alpha$-phen-7 & 64 & 16 & $>128$ & $>128$ & $>128$ & $>128$ \\
\hline$\alpha-\mathrm{Me}_{2}$ phen-7 & 64 & 16 & $\geq 128$ & $\geq 128$ & $>128$ & $>128$ \\
\hline$\alpha-\mathrm{Me}_{4}$ phen-7 & 64 & 4 & $32-64$ & 16 & $>128$ & $\geq 128$ \\
\hline$\alpha-\mathrm{NO}_{2}$ phen-7 & 128 & $\geq 128$ & $>128$ & $>128$ & $>128$ & $>128$ \\
\hline$\alpha$-phen-12 & 4 & 2 & $8-16$ & 32 & 32 & $\geq 64$ \\
\hline$\beta$-phen-12 & $4-8$ & 8 & $16-32$ & 32 & 32 & 128 \\
\hline$\left(\mathrm{Me}_{4} \text { phen }\right)_{3}$ & 1 & 1 & 8 & 8 & $16-32$ & 64 \\
\hline Rubb $_{7}$ & $\geq 32$ & $\geq 16$ & 32 & 32 & 64 & $>128$ \\
\hline $\mathrm{Rubb}_{12}$ & 2 & 2 & 2 & 2 & $2-4$ & 64 \\
\hline Gentamicin & 2 & 1 & 2 & 1 & 4 & 1 \\
\hline
\end{tabular}

Table 6 Octanol/water partition coefficients $(\log P)$ for the ruthenium complexes

\begin{tabular}{|c|c|c|}
\hline Metal complex & Charge & $\log P$ \\
\hline$\alpha$-phen-7 & 2 & $-1.83 \pm 0.04$ \\
\hline$\alpha-\mathrm{Me}_{2}$ phen-7 & 2 & $-1.41 \pm 0.07$ \\
\hline$\alpha-\mathrm{Me}_{4}$ phen- 7 & 2 & $-1.33 \pm 0.03$ \\
\hline$\alpha-\mathrm{NO}_{2}$ phen- 7 & 2 & $-1.58 \pm 0.09$ \\
\hline$\alpha$-phen- $12^{a}$ & 2 & -0.9 \\
\hline$\beta$-phen-12 ${ }^{a}$ & 2 & -1.0 \\
\hline$\left(\mathrm{Me}_{4} \text { phen }\right)_{3}{ }^{a}$ & 2 & -1.35 \\
\hline $\mathrm{Rubb}_{7} b$ & 4 & -3.4 \\
\hline $\operatorname{Rubb}_{12}^{b}$ & 4 & -2.7 \\
\hline $\operatorname{Rubb}_{10} b$ & 4 & -3.3 \\
\hline
\end{tabular}

${ }^{a}$ Results from ref. $10 .{ }^{b}$ Results from ref. 7.
PAO1 were determined by measuring the concentration of the complex remaining in the culture supernatant after removing the bacteria by centrifugation. The concentration of the ruthenium complex in the supernatant was calculated from a luminescence calibration curve obtained by adding known concentrations of the ruthenium complex to a blank supernatant. As the luminescence of the ruthenium complexes varied with the different broths and supernatants for each bacterial strain, a calibration curve was determined for each complex in the supernatant of each bacterial strain.

Fig. 6 shows the cellular accumulation of the ruthenium complexes against MRSA, UPEC and PAO1 at various time points. The uptake of the ruthenium complexes was greater with the Gram-positive bacteria compared with the Gram-negative strains, with PAO1 showing the lowest accumulation - consistent with the observed MIC/MBC values. In addition, while the accumulation in Gram-positive bacteria gradually increased with time for all complexes, the same result was not observed for the Gram-negative bacteria strains. Interestingly, the cellular accumulation of the cis- $\alpha-\left[\mathrm{Ru}\left(\mathrm{Me}_{4} \text { phen }\right)\left(\mathrm{bb}_{7}\right)\right]^{2+}$ and $\left[\mathrm{Ru}\left(\mathrm{Me}_{4} \text { phen }\right)_{3}\right]^{2+}$ in PAO1 reached its highest within 15 minutes and then maintained this level; in contrast, the accumulation of $\mathrm{Rubb}_{12}$ and $c i s-\alpha-\left[\mathrm{Ru}(\text { phen })\left(\mathrm{bb}_{12}\right)\right]^{2+}$ steadily increased over the two hours. Moreover, the uptake of the cis$\alpha-\left[\mathrm{Ru}\left(\mathrm{phen}^{\prime}\right)\left(\mathrm{bb}_{7}\right)\right]^{2+}$ family is consistent with the MIC/MBC values, with the degree of methylation of the phen ligand correlated with the accumulation. However, there was significantly less accumulation of $c i s-\alpha-\left[\mathrm{Ru}\left(\mathrm{Me}_{4} \text { phen }\right)\left(\mathrm{bb}_{7}\right)\right]^{2+}$ in PAO1 than with $\left[\mathrm{Ru}\left(\mathrm{Me}_{4} \text { phen }\right)_{3}\right]^{2+}, \quad c i s-\alpha-\left[\mathrm{Ru}(\mathrm{phen})\left(\mathrm{bb}_{12}\right)\right]^{2+}$ and Rubb $_{12}$ despite the activity for cis- $\alpha-\left[\mathrm{Ru}\left(\mathrm{Me}_{4} \text { phen }\right)\left(\mathrm{bb}_{7}\right)\right]^{2+}$ 


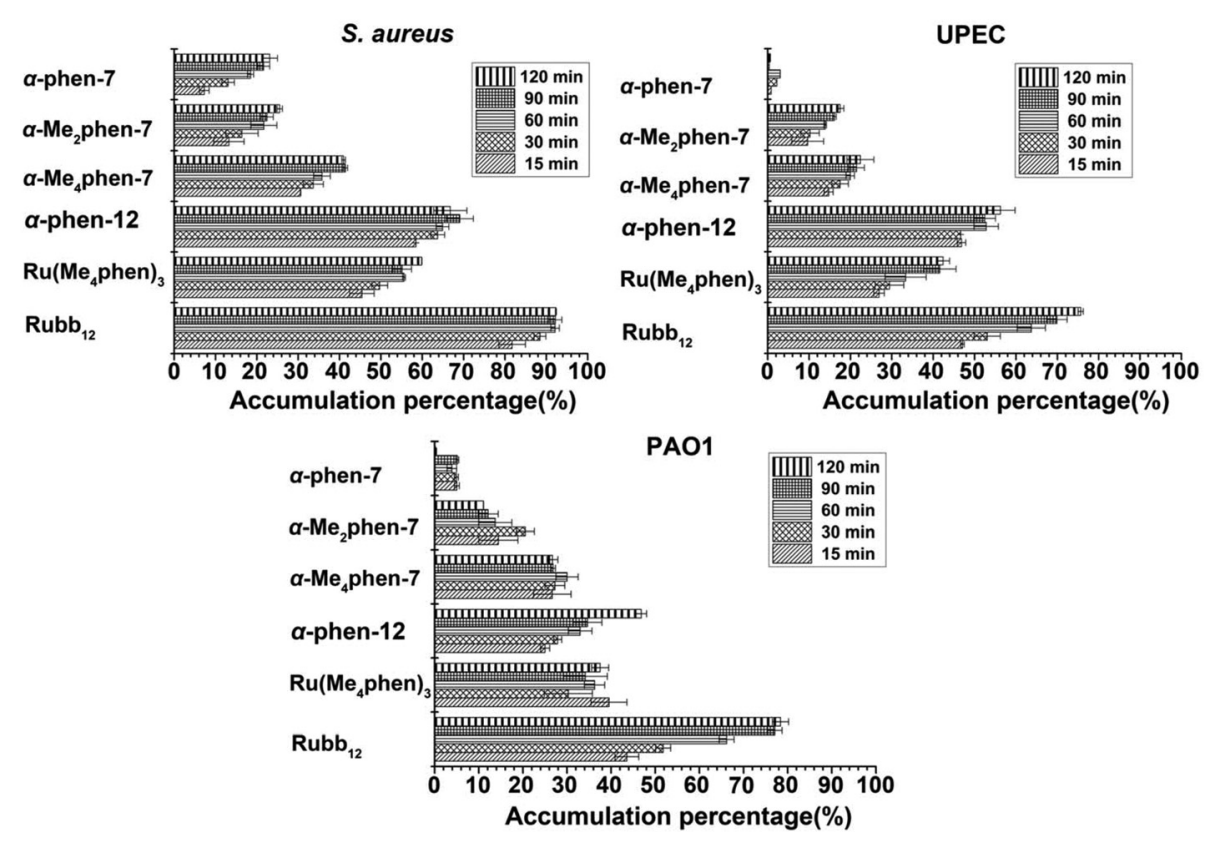

Fig. 6 Cellular accumulation of the cis- $\alpha-\left[R u\left(p h e n^{\prime}\right)\left(b_{7}\right)\right]^{2+},\left[R u\left(M_{4}{ }_{4} \text { phen }\right)_{3}\right]^{2+}$ and $R^{2} b_{12}$ complexes into bacteria after incubation for $15,30,60$, 90 and 120 minutes.

being two- to four-fold higher than for the other three complexes.

\section{Interaction with DNA}

As previous studies showed that the di-, tri- and tetra-nuclear ruthenium complexes linked by the $\mathrm{bb}_{n}$ ligand preferentially localise with DNA and RNA in bacterial and eukaryotic cells, ${ }^{18,19}$ it was of interest to examine the DNA binding affinity of the $\left[\mathrm{Ru}\left(\mathrm{phen}^{\prime}\right)\left(\mathrm{bb}_{n}\right)\right]^{2+}$ complexes to DNA. The binding of the ruthenium complexes to calf-thymus (CT)-DNA was examined by UV/Vis spectroscopy and the intrinsic binding constants $K$ to DNA calculated by a non-linear least-square method using eqn (1). ${ }^{20}$

$$
\begin{gathered}
\left(\varepsilon_{\mathrm{a}}-\varepsilon_{\mathrm{f}}\right) /\left(\varepsilon_{\mathrm{b}}-\varepsilon_{\mathrm{f}}\right)=\left(b-\left(b^{2}-2 K^{2} C_{\mathrm{t}}[\mathrm{DNA}] / s\right)^{1 / 2}\right) / 2 K C_{\mathrm{t}} \\
b=1+K C_{\mathrm{t}}+K[\mathrm{DNA}] / 2 s
\end{gathered}
$$

where [DNA] is the concentration of DNA in M (nucleotide); $\varepsilon_{\mathrm{a}}$ is the molar absorption coefficient observed for the ${ }^{1} \mathrm{MLCT}$ absorption band at a given DNA concentration; $\varepsilon_{\mathrm{f}}$ is the molar absorption coefficient of the free complex without DNA; $\varepsilon_{\mathrm{b}}$ is the molar absorption coefficient of the complex fully bound to DNA; $K$ is the equilibrium-binding constant in $\mathrm{M}^{-1}$; and $C_{\mathrm{t}}$ is the total metal complex concentration and $s$ is the binding site size.

All $\left[\mathrm{Ru}\left(\mathrm{phen}^{\prime}\right)\left(\mathrm{bb}_{n}\right)\right]^{2+}$ complexes showed strong binding to CT-DNA, with binding constants of approximately $1 \times 10^{7} \mathrm{M}^{-1}$ (see Table 7). As the DNA binding affinities were surprisingly strong, the well-known high affinity metallointercalator complex $\left[\mathrm{Ru}(\text { phen })_{2}(\mathrm{dppz})\right]^{2+}$ (ref. 21) was examined as a control. The observed binding constant, $2 \times 10^{6} \mathrm{M}^{-1}$, was comparable with previously reported values. ${ }^{20,21}$ The $c i s-\alpha-[\mathrm{Ru}(5-$
Table 7 The CT-DNA binding constants $(K)$ of the mononuclear ruthenium complexes

\begin{tabular}{ll}
\hline Complexes & $K\left[\mathrm{M}^{-1}\right] \times 10^{7}$ \\
\hline$\alpha$-phen-7 & $1.73 \pm 0.26$ \\
$\alpha-\mathrm{Me}_{2}$ phen-7 & $0.42 \pm 0.04$ \\
$\alpha-\mathrm{Me}_{4}$ phen-7 & $1.46 \pm 0.47$ \\
$\alpha$ - $\mathrm{NO}_{2}$ phen-7 & $4.22 \pm 0.93$ \\
$\alpha$-phen-12 & $0.59 \pm 0.05$ \\
$\beta$-phen-12 & $0.20 \pm 0.02$ \\
$(\text { phen })_{2} \mathrm{dppz}$ & $0.21 \pm 0.05$ \\
$\left(\mathrm{Me}_{4} \text { phen }\right)_{3}$ & $0.25 \pm 0.01$
\end{tabular}

$\mathrm{NO}_{2}$ phen $\left.\left(\mathrm{bb}_{7}\right)\right]^{2+}$ complex exhibited the strongest binding affinity. However, no significant differences in the DNA binding affinities between the cis- $\alpha-\left[\mathrm{Ru}(\mathrm{phen})\left(\mathrm{bb}_{7}\right)\right]^{2+}$ and cis$\alpha-\left[\operatorname{Ru}\left(\mathrm{Me}_{4} \mathrm{phen}\right)\left(\mathrm{bb}_{7}\right)\right]^{2+}$ complexes were observed. In addition, the binding constants of $c i s-\alpha-\left[\mathrm{Ru}\left(\mathrm{phen}^{\prime}\right)\left(\mathrm{bb}_{7}\right)\right]^{2+}$ isomers are higher than for the $\left[\mathrm{Ru}(\mathrm{phen})\left(\mathrm{bb}_{12}\right)\right]^{2+}$ analogues, which is consistent with reported values for the DNA binding affinities for $\left[\mathrm{Ru}(\text { phen })\left(\mathrm{bb}_{10}\right)\right]^{2+}$ and $\left[\mathrm{Ru}(\text { phen })\left(\mathrm{bb}_{12}\right)\right]^{2+}$ analogues. ${ }^{17}$

\section{Discussion}

Due to the emergence of drug-resistant bacteria there is a need to develop new classes of antimicrobial agents. We have previously shown ${ }^{17}$ that ruthenium(II) complexes containing bis[4(4'-methyl-2,2'-bipyridyl)]-1, $n$-alkane ( $\mathrm{bb}_{n}$; for $n=10$ and 12 ) as a tetradentate ligand in a mononuclear complex (rather than as a bridging ligand in oligonuclear complexes) exhibit excellent antimicrobial activity in terms of MIC values, against both Gram-positive and Gram-negative bacteria. In this study 
we have extended the $\left[\mathrm{Ru}(\mathrm{phen})\left(\mathrm{bb}_{n}\right)\right]^{2+}$ family of complexes by altering both the $\mathrm{bb}_{n}$ and phen ligands, and report their antimicrobial activities in terms of both MIC and MBC values.

In the syntheses of the $\left[\mathrm{Ru}\left(\mathrm{phen}^{\prime}\right)\left(\mathrm{bb}_{7}\right)\right]^{2+}$ complexes, both the $c i s-\alpha$ and $c i s-\beta$ isomers were initially observed. However, in contrast to the $\mathrm{bb}_{10}$ and $\mathrm{bb}_{12}$ homologues of $\left[\mathrm{Ru}(\mathrm{phen}) \mathrm{bb}_{n}\right]^{2+}$, the $c i s-\beta$ isomer was not stable and converted predominantly to the cis- $\alpha$ isomer over time or in harsh conditions. It is concluded that the cis- $\beta$ is a kinetic product but the cis- $\alpha$ is the thermodynamic product. The DFT calculations demonstrated that the cis- $\beta$ complex is highly strained and considerably less stable than the corresponding cis- $\alpha$ isomer. As ruthenium(II) complexes with three bidentate chelating ligands groups (as is essentially the case in $\left[\mathrm{Ru}\left(\mathrm{phen}^{\prime}\right)\left(\mathrm{bb}_{7}\right)\right]^{2+}$ - but with an additional chelate ring involving the polymethylene chain in the tetradendate $\left(b_{7}\right)$ are considered to be "kinetically inert" the conversion from the $c i s-\beta$ to the $c i s-\alpha$ is unusual, although isomerisation of ruthenium(II) complexes with monodentate ligands, e.g. pyridine, is well known. ${ }^{22}$ Examples of photoactivated isomerisation, ligand loss and degradation of tris(bidentate) complexes, e.g. $\left[\mathrm{Ru}(\mathrm{bpy})_{3}\right]^{2+}$, are known ${ }^{23}$ and it has been suggested that ruthenium(II) complexes with distorted octahedral geometry photodecompose through ligand dissociation. ${ }^{24}$ The present DFT calculations have indicated that the cis- $\beta-\left[\mathrm{Ru}\left(\mathrm{Me}_{4} \mathrm{phen}\right)\left(\mathrm{bb}_{7}\right)\right]^{2+}$ complex is unstable and the octahedral geometry is distorted: consequently, the cis- $\beta$ and cis- $\alpha$ isomers can interconvert but demonstrably by a thermal mechanism in this case, as the presence of light does not affect the process.

The MIC/MBC values presented in this study demonstrate that apart from cis- $\alpha-\left[\mathrm{Ru}\left(5-\mathrm{NO}_{2} \text { phen }\right)\left(\mathrm{bb}_{7}\right)\right]^{2+}$, the cis- $\alpha-$ $\left[\mathrm{Ru}\left(\mathrm{phen}^{\prime}\right)\left(\mathrm{bb}_{7}\right)\right]^{2+}$ complexes are active against Gram-positive bacteria but exhibit variable activity towards Gram-negative species. However, the cis- $\alpha-\left[\mathrm{Ru}\left(\mathrm{Me}_{4}-\mathrm{phen}\right)\left(\mathrm{bb}_{7}\right)\right]^{2+}$ complex shows good activity (MICs $\leq 8 \mu \mathrm{g} \mathrm{mL}^{-1}$ ) against both Grampositive and Gram-negative bacteria, including the notoriously drug-resistant $P$. aeruginosa. Ruthenium(II) complexes, ${ }^{12,16}$ like most antimicrobial agents, ${ }^{25}$ have generally not shown good activity against $P$. aeruginosa. Recently we reported that the cis$\alpha-\left[\mathrm{Ru}(\mathrm{phen})\left(\mathrm{bb}_{12}\right)\right]^{2+}$ complex does readily accumulate in $P$. aeruginosa and exhibits good activity against this bacterial strain. ${ }^{17}$ The results of the current study indicate that cis- $\alpha$ $\left[\mathrm{Ru}\left(\mathrm{Me}_{4} \mathrm{phen}\right)\left(\mathrm{bb}_{7}\right)\right]^{2+}$ is slightly more active (in terms of MIC) against $P$. aeruginosa than $c i s-\alpha-\left[\operatorname{Ru}(\mathrm{phen})\left(\mathrm{bb}_{12}\right)\right]^{2+}$. However, a sixteen-fold difference between the MBC and MIC values for cis- $\alpha-\left[\mathrm{Ru}\left(\mathrm{Me}_{4} \mathrm{phen}\right)\left(\mathrm{bb}_{7}\right)\right]^{2+}$ against $P$. aeruginosa was observed, compared to the two-fold difference for $\left[\mathrm{Ru}\left(\mathrm{Me}_{4} \mathrm{phen}\right)_{3}\right]^{2+}$ and a four-fold difference for $c i s-\alpha-\left[\mathrm{Ru}(\mathrm{phen})\left(\mathrm{bb}_{12}\right)\right]^{2+}$. This suggests the $c i s-\alpha-\left[\mathrm{Ru}\left(\mathrm{Me}_{4} \text { phen }\right)\left(\mathrm{bb}_{7}\right)\right]^{2+}$ complex may exert its antimicrobial activity through a different mechanism. Furthermore, and of note, of all the mono-, di-, tri- and tetranuclear ruthenium complexes that incorporate the $\mathrm{bb}_{n}$ ligand that we have examined, ${ }^{12-17}$ the $c i s-\alpha-\left[\mathrm{Ru}\left(\mathrm{Me}_{4} \text { phen }\right)\left(\mathrm{bb}_{7}\right)\right]^{2+}$ complex displays the most similar MIC values but the most varied $\mathrm{MBC}$ values across a range of Gram-positive and Gramnegative bacteria. This is also consistent with the cis- $\alpha$ -
$\left[\mathrm{Ru}\left(\mathrm{Me}_{4} \text { phen }\right)\left(\mathrm{bb}_{7}\right)\right]^{2+}$ complex exerting its antimicrobial activity through a different mechanism. Alternatively, the highly variable MBC values observed for $c i s-\alpha-\left[\mathrm{Ru}\left(\mathrm{Me}_{4} \mathrm{phen}\right)\left(\mathrm{bb}_{7}\right)\right]^{2+}$ could be due to different resistance mechanisms - e.g. the up-regulation of efflux pumps and plasmid-mediated resistance mechanisms - that exist between bacteria, even closely related bacteria such as the $E$. coli strains UPEC and APEC.

While we have previously reported the antimicrobial activities of mono- and oligo-nuclear ruthenium complexes that incorporate the $\mathrm{bb}_{n}$ ligand, the present study also examined the effects of substituents on the 1,10-phenanthroline ligand. The antimicrobial activities were examined in relationship to the electron-withdrawing/-donating effect of substituents on the phenanthroline ligand through the analyses of their respective cellular accumulations and DNA binding. The results clearly demonstrate the importance of both cellular accumulation and DNA binding. The cis- $\alpha-\left[\mathrm{Ru}\left(5-\mathrm{NO}_{2}\right.\right.$ phen)$\left.\left(b_{7}\right)\right]^{2+}$ complex bound DNA with the highest affinity but displayed no antimicrobial activity because it was not taken up by the bacterial cells. Given that $c i s-\alpha-\left[\mathrm{Ru}\left(5-\mathrm{NO}_{2} \mathrm{phen}\right)\left(\mathrm{bb}_{7}\right)\right]^{2+}$ is slightly more lipophilic than $c i s-\alpha-\left[\operatorname{Ru}(p h e n)\left(b_{7}\right)\right]^{2+}$, the lack of uptake and antimicrobial activity of the nitro-substituted complex suggests that relatively minor charges of the charge density on the ruthenium centre play a critical role in the diffusion of the ruthenium complex across the bacterial membrane. The introduction of methyl substituents on the 1,10phenanthroline progressively increased the cellular accumulation and antimicrobial activities of the $c i s-\alpha-\left[\mathrm{Ru}\left(\mathrm{phen}^{\prime}\right)-\right.$ $\left.\left(b_{7}\right)\right]^{2+}$ complexes, especially against Gram-negative bacteria.

All the ruthenium complexes showed better accumulation in the Gram-positive than the Gram-negative bacteria, suggesting a clear relationship between the cellular accumulation and MIC, but only to a point. The cis- $\alpha-[\mathrm{Ru}(\mathrm{phen})-$ $\left.\left(b_{12}\right)\right]^{2+}$ exhibited similar antimicrobial activity but a higher level of cellular accumulation than the $c i s-\alpha-\left[\operatorname{Ru}(\operatorname{phen})\left(\mathrm{bb}_{7}\right)\right]^{2+}$ across the bacteria, consistent with increasing lipophilicity $(\log P=-0.9$ and -1.83 respectively). Furthermore, cis- $\alpha-[\mathrm{Ru}-$ $\left.\left(\mathrm{Me}_{4} \mathrm{phen}\right)\left(\mathrm{bb}_{7}\right)\right]^{2+}$ has similar or even higher activity against Gram-negative bacteria than $\left[\mathrm{Ru}\left(\mathrm{Me}_{4} \text { phen }\right)_{3}\right]^{2+}$ in terms of MIC, but cis- $\alpha-\left[\mathrm{Ru}\left(\mathrm{Me}_{4} \mathrm{phen}\right)\left(\mathrm{bb}_{7}\right)\right]^{2+}$ showed lower cellular accumulation in the Gram-negative bacteria compared to $\left[\mathrm{Ru}\left(\mathrm{Me}_{4} \text { phen }\right)_{3}\right]^{2+}$. Notably, there was a different pattern of accumulation in $P$. aeruginosa between the $c i s-\alpha-\left[\mathrm{Ru}\left(\mathrm{Me}_{4} \mathrm{phen}\right)-\right.$ $\left.\left(\mathrm{bb}_{7}\right)\right]^{2+}$ and $\left[\mathrm{Ru}\left(\mathrm{Me}_{4} \text { phen }\right)_{3}\right]^{2+}$ complexes compared with the cis- $\alpha-\left[\mathrm{Ru}(\mathrm{phen})\left(\mathrm{bb}_{12}\right)\right]^{2+}$ and $\mathrm{Rubb}_{12}$ complexes. The uptake of the latter two complexes steadily increased over the two-hour time period; whereas for the former complexes, maximum accumulation was achieved at the first time point (15 minutes), with the cellular accumulation then remaining constant up to two hours. These results potentially suggest that $P$. aeruginosa may have an effective efflux pump against the $c i s-\alpha-\left[\mathrm{Ru}\left(\mathrm{Me}_{4}\right.\right.$ phen)$\left.\left(\mathrm{bb}_{7}\right)\right]^{2+}$ and $\left[\mathrm{Ru}\left(\mathrm{Me}_{4} \mathrm{phen}\right)_{3}\right]^{2+}$ complexes, or that the ruthenium complexes incorporating the $\mathrm{bb}_{12}$ ligand can permeabilise the bacterial membrane.

The $c i s-\alpha-\left[\mathrm{Ru}\left(\mathrm{phen}^{\prime}\right)\left(\mathrm{bb}_{7}\right)\right]^{2+}$ complexes showed surprisingly high DNA binding affinity, even binding more strongly 
than the established high-affinity metallointercalator $\left[\mathrm{Ru}(\mathrm{phen})_{2}(\mathrm{dppz})\right]^{2+}$. The high DNA binding affinity of the cis$\alpha-\left[\mathrm{Ru}\left(\mathrm{phen}^{\prime}\right)\left(\mathrm{bb}_{7}\right)\right]^{2+}$ complexes is likely to be due to an increased hydrophobic effect coupled with the decreased ability of the complexes to self-associate in water due to steric clashes between the methyl groups. The observations that cis$\alpha-\left[\mathrm{Ru}\left(\mathrm{Me}_{4} \text { phen }\right)\left(\mathrm{bb}_{7}\right)\right]^{2+}$ shows lower accumulation but exhibits the same or slightly better antimicrobial activities against the Gram-negative bacteria than the $\left[\mathrm{Ru}\left(\mathrm{Me}_{4} \text { phen }\right)_{3}\right]^{2+}$ or cis- $\alpha-$ $\left[\mathrm{Ru}(\text { phen })\left(\mathrm{bb}_{12}\right)\right]^{2+}$ complexes could suggest DNA (and RNA) binding is at least one aspect of the antimicrobial activity. Indeed, we have previously demonstrated that the dinuclear and oligonuclear ruthenium complexes target DNA and RNA in bacteria and eukaryotic cells. ${ }^{18,19}$ However, the mechanism of action for kinetically-inert polypyridylruthenium(II) complexes is still a matter of debate. In addition to nucleic acid binding, a variety of studies have proposed that these ruthenium complexes can permeabilise the bacterial membrane, ${ }^{26,27}$ inhibit the activity of important enzymes, ${ }^{28}$ or induce the production of reactive oxygen species (ROS) that could cause DNA damage and bacterial cell death. ${ }^{29}$ It is likely that for each ruthenium complex a number of these potential mechanisms are simultaneously active, with the balance between the various mechanisms modulated by the specific chemical structure.

\section{Conclusions}

The mononuclear cis- $\alpha-\left[\mathrm{Ru}\left(\mathrm{Me}_{4} \text { phen }\right)\left(\mathrm{bb}_{7}\right)\right]^{2+}$ complex has significant potential as an antimicrobial agent. In this study, it has been shown that it is highly active against $P$. aeruginosa. Our results also suggest that the antimicrobial activity differences between the cis- $\alpha-\left[\mathrm{Ru}\left(\mathrm{phen}^{\prime}\right)\left(\mathrm{bb}_{7}\right)\right]^{2+}$ complex and the mononuclear $\left[\mathrm{Ru}(\text { phen })\left(\mathrm{bb}_{12}\right)\right]^{2+}$ complexes previously studied are significant in terms of the electron density imposed by substituents on the 1,10-phenanthroline ligand. As a consequence, and given that the structure can be readily modified, it is possible that ruthenium(II) complexes can be customised to particular bacteria. Our studies continue on this project: the toxicity on eukaryotic cells of $\left[\mathrm{Ru}\left(\mathrm{phen}^{\prime}\right)\left(\mathrm{bb}_{n}\right)\right]^{2+}$ species will be explored and a further probe of the working mechanisms of this class of ruthenium complexes is on the way.

\section{Experimental}

\section{Physical measurements}

${ }^{1} \mathrm{H}$ and ${ }^{13} \mathrm{C}$ NMR spectra were recorded on a Varian Advance $400 \mathrm{MHz}$ spectrometer at room temperature $\left\{\mathrm{CDCl}_{3}(99.8 \%\right.$, $\mathrm{CIL}), \mathrm{CD}_{3} \mathrm{CN}$ (>99.8\%, Aldrich), or $\mathrm{CD}_{3} \mathrm{OD}(>99.8 \%$, Aldrich)\}. Luminescence was measured on a Cary Eclipse Fluorescence Spectrophotometer with $\lambda_{\mathrm{ex}}=488 \mathrm{~nm}$ : emission spectra were collected from $\lambda_{\text {em }}=500-800 \mathrm{~nm}$. Absorbance $(200-600 \mathrm{~nm})$ was measured on a VARIAN CARY 50 Probe UV-visible spectrophotometer. Mass-spectroscopic analysis was performed by the RSC Mass-Spectrometry Facility (Research School of Chemistry, Australian National University, Canberra), and the Campbell Microanalytical Laboratory (Chemistry Department, University of Otago) performed the microanalyses.

\section{Materials and methods}

Potassium hexafluorophosphate $\left(\mathrm{KPF}_{6}\right)$, and 1,10-phenanthroline and its derivatives, were purchased from Aldrich and used as supplied. Amberlite IRA-402 (chloride form) anion-exchange resin and SP Sephadex C-25 cation exchanger were obtained from GE Health Care Bioscience. Cation-adjusted MuellerHinton broth (CAMHB), Mueller-Hinton Agar2 and the antibiotic gentamicin were purchased from Sigma-Aldrich (UK). LB broth was purchased from Formedium (UK).

The syntheses of ligands $\mathrm{bb}_{n}(n=7,12)$ and cis$\left[\mathrm{RuCl}_{2}(\mathrm{DMSO})_{4}\right]$ were performed according to previously reported methods. ${ }^{30,31}$

\section{Syntheses of metal complexes}

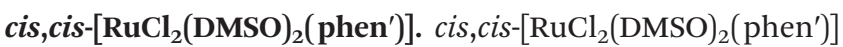
complexes were synthesised using schemes based on previously reported methods. ${ }^{32}$ A suspension of $1 \mathrm{mmol}$ of cis- $^{-}$ $\left[\mathrm{RuCl}_{2}(\mathrm{DMSO})\right]$ and $1 \mathrm{mmol}$ of the appropriate substituted 1,10-phenanthroline was refluxed in toluene $(10 \mathrm{~mL})$ for $2 \mathrm{~h}$. The solid that separated was filtered and washed with toluene and then with diethylether. For cis, cis-[ $\operatorname{RuCl}_{2}(\mathrm{DMSO})_{2}($ phen)], cis,cis- $\left[\mathrm{RuCl}_{2}(\mathrm{DMSO})_{2}\left(\mathrm{Me}_{4}\right.\right.$ phen $\left.)\right]$ and cis, cis-[ $\mathrm{RuCl}_{2}(\mathrm{DMSO})_{2}$ $\left(5-\mathrm{NO}_{2}\right.$ phen)], the pure product was realised after filtration. For cis,cis-[ $\mathrm{RuCl}_{2}(\mathrm{DMSO})_{2}\left(\mathrm{Me}_{2}\right.$ phen $\left.)\right]$, after filtration the crude product was dissolved in a minimal volume of dichloromethane (DCM) and then loaded onto a silica gel column (230-400 mesh; $3 \mathrm{~cm}$ diam). The desired product and side products were gradient-eluted using 1-4\% (v/v) methanol in DCM. The purity and contents of each fraction were determined by TLC (silica gel), using 5\% (v/v) methanol in DCM as eluent. The purest fractions were combined and the solvent was removed in vacuo to give light yellow-green solids: yields: cis,cis-[RuCl ${ }_{2}(\mathrm{DMSO})_{2}$ (phen)], yellow-green powder - 83\%; cis,cis$\left[\mathrm{RuCl}_{2}(\mathrm{DMSO})_{2}\left(\mathrm{Me}_{4} \mathrm{phen}\right)\right]$, green-brown powder - 85\%; cis,cis$\left[\mathrm{RuCl}_{2}(\mathrm{DMSO})_{2}\left(\mathrm{Me}_{2}\right.\right.$ phen $\left.)\right]$, light yellow-green powder - 70\%; cis, cis-[RuCl${ }_{2}(\mathrm{DMSO})_{2}\left(5-\mathrm{NO}_{2}\right.$ phen $\left.)\right]$, brown powder $-90 \%$.

cis,cis-[RuCl ${ }_{2}$ (DMSO) $)_{2}$ (phen)]. The ${ }^{1} \mathrm{H}$ NMR and mass-spectral data were consistent with that reported previously for this complex. $^{33}$

cis,cis-[ $\operatorname{RuCl}_{2}(\mathrm{DMSO})_{2}\left(\mathrm{Me}_{2}\right.$ phen $\left.)\right]$ Anal. calcd for $\mathrm{C}_{18} \mathrm{H}_{24} \mathrm{Cl}_{2} \mathrm{~N}_{2} \mathrm{O}_{2} \mathrm{RuS}_{2}$ : C, 40.3\%; H, 4.51\%; N, 5.2\%. Found: C, 40.9\%; H, 4.60\%; N, 5.1\%. ${ }^{1} \mathrm{H}$ NMR (400 $\mathrm{MHz} \mathrm{CDCl}_{3}$ ): $\delta 9.96$ (d, $J=5.6 \mathrm{~Hz}, 1 \mathrm{H}$; H2 or H9); 9.80 (d, $J=5.6 \mathrm{~Hz}, 1 \mathrm{H}$; H2 or H9); $8.14(\mathrm{~d}, J=9.6 \mathrm{~Hz}, 1 \mathrm{H}$; H5 or H6); 8.10 (d, $J=9.2 \mathrm{~Hz}, 1 \mathrm{H}$; H5 or H6); 7.74 (d, $J=5.6 \mathrm{~Hz}, 1 \mathrm{H}$; H3 or H8); 7.57 (d, $J=5.6 \mathrm{~Hz}, 1 \mathrm{H}$; H3 or H8); 3.58 (d, $\left.J=10.8 \mathrm{~Hz}, 6 \mathrm{H} ; 2 \times \mathrm{CH}_{3}\right) ; 3.15(\mathrm{~s}, 3 \mathrm{H}$; $\left.\mathrm{S}\left(\mathrm{CH}_{3}\right)\right) ; 2.93\left(\mathrm{~s}, 3 \mathrm{H} ; \mathrm{S}\left(\mathrm{CH}_{3}\right)\right), 2.87$ (s, 3H; S( $\left.\left.\mathrm{CH}_{3}\right)\right) ; 2.50(\mathrm{~s}, 3 \mathrm{H}$; $\left.\mathrm{S}\left(\mathrm{CH}_{3}\right)\right)$. TOF MS (ESI+): most abundant ion found for $[\mathrm{M}+$ $\mathrm{Na}]^{+}, m / z$ 559.0. Calc. for $\mathrm{Ru}\left[\mathrm{C}_{18} \mathrm{H}_{24} \mathrm{Cl}_{2} \mathrm{~N}_{2} \mathrm{NaO}_{2} \mathrm{~S}_{2}\right]^{+}, m / z 558.96$. cis,cis-[ $\mathbf{R u C l}_{2}(\mathrm{DMSO})_{2}\left(\mathbf{M e}_{4}\right.$ phen $\left.)\right]$ Anal. calcd for $\mathrm{C}_{20} \mathrm{H}_{28} \mathrm{Cl}_{2} \mathrm{~N}_{2} \mathrm{O}_{2} \mathrm{RuS}_{2}$ : C, 42.6\%; H, 5.00\%; N, 5.0\%. Found: C, 
42.1\%; H, 4.91\%; N, 5.0\%. ${ }^{1} \mathrm{H}$ NMR (400 $\mathrm{MHz}, \mathrm{CDCl}_{3}$ ): $\delta 9.80$ (s, $1 \mathrm{H} ; \mathrm{H} 2$ or H9); 9.75 (s, 1H; H2 or H9); 8.14 (d, $J=9.2 \mathrm{~Hz}$, 1H; H5 or H6); 8.10 (d, $J=9.2 \mathrm{~Hz}, 1 \mathrm{H}$; H5 or H6); 3.61 (d, $J=$ $\left.7.2 \mathrm{~Hz}, 6 \mathrm{H} ; 2 \times \mathrm{CH}_{3}\right) ; 3.18\left(\mathrm{~s}, 3 \mathrm{H} ; \mathrm{S}\left(\mathrm{CH}_{3}\right)\right) ; 2.76(\mathrm{~s}, 6 \mathrm{H} ; 2 \times$ $\left.\mathrm{CH}_{3}\right) ; 2.65\left(\mathrm{~s}, \quad 3 \mathrm{H} ; \mathrm{S}\left(\mathrm{CH}_{3}\right)\right) ; 2.60\left(\mathrm{~s}, 3 \mathrm{H} ; \mathrm{S}\left(\mathrm{CH}_{3}\right)\right) ; 2.41$ $\left(\mathrm{s}, 3 \mathrm{H} ; \mathrm{S}\left(\mathrm{CH}_{3}\right)\right)$. TOF MS (ESI+): most abundant ion found for $[\mathrm{M}+\mathrm{Na}]^{+}, m / z$ 587.0. Calc. for $\mathrm{Ru}\left[\mathrm{C}_{20} \mathrm{H}_{28} \mathrm{Cl}_{2} \mathrm{~N}_{2} \mathrm{NaO}_{2} \mathrm{~S}_{2}{ }^{+}, m / z\right.$ 586.99.

cis,cis-[ $\left.\mathrm{RuCl}_{2}(\mathrm{DMSO})_{2}\left(\mathbf{5}-\mathrm{NO}_{2} \mathrm{phen}\right)\right] \cdot \mathbf{H}_{2} \mathrm{O}$. Anal. calcd for $\mathrm{C}_{16} \mathrm{H}_{21} \mathrm{Cl}_{2} \mathrm{~N}_{3} \mathrm{O}_{5} \mathrm{RuS}_{2}$ : C, 33.6\%; H, 3.70\%; N, 7.4\%. Found: C, $33.5 \%$; H, 3.59\%; N, 7.3\%. ${ }^{1} \mathrm{H}$ NMR (400 MHz, $\left.\mathrm{CDCl}_{3}\right): \delta 10.33$ (dd, $J=1.2,5.2 \mathrm{~Hz}, 1 \mathrm{H}$; H2 or H9, one isomer); 10.30 (dd, $J=$ 1.6, $5.6 \mathrm{~Hz}, 1 \mathrm{H}$; $\mathrm{H} 2$ or H9, another isomer); 10.17 (dd, $J=1.2$, $5.6 \mathrm{~Hz}, 1 \mathrm{H}$; H2 or H9, one isomer); 10.10 (dd, $J=0.8,5.2 \mathrm{~Hz}$, $1 \mathrm{H}$; $\mathrm{H} 2$ or $\mathrm{H} 9$, another isomer); $9.33(\mathrm{dd}, J=1.2,8.4 \mathrm{~Hz}, 1 \mathrm{H}$; $\mathrm{H} 4$ or $\mathrm{H} 7$, one isomer); 9.18 (dd, $J=1.2,8.8 \mathrm{~Hz}, 1 \mathrm{H}$; $\mathrm{H} 4$ or $\mathrm{H} 7$, another isomer); 8.92 (d, $J=5.2 \mathrm{~Hz}, 1 \mathrm{H}, \mathrm{H} 6$ for two isomers); 8.68 (dd, $J=1.2,8.0 \mathrm{~Hz}, 1 \mathrm{H} ; \mathrm{H} 4$ or $\mathrm{H} 7$, one isomer); 8.56 (dd, $J=1.2,7.6 \mathrm{~Hz}, 1 \mathrm{H}$; $\mathrm{H} 4$ or $\mathrm{H} 7$, another isomer $) ; 8.12(\mathrm{~m}, 2 \mathrm{H}$, $\mathrm{H} 3 / \mathrm{H} 8$, one isomer); $7.94(\mathrm{~m}, 2 \mathrm{H}, \mathrm{H} 3 / \mathrm{H} 8$, another isomer); 3.61 (d, $J=2 \mathrm{~Hz}, 6 \mathrm{H} ; 2 \times \mathrm{CH}_{3}$, one isomer); 3.57 (d, $J=4.4 \mathrm{~Hz}$, $6 \mathrm{H} ; 2 \times \mathrm{CH}_{3}$, another isomer); $3.23\left(\mathrm{~s}, 3 \mathrm{H} ; \mathrm{S}\left(\mathrm{CH}_{3}\right)\right.$, one isomer); $3.20\left(\mathrm{~s}, 3 \mathrm{H} ; \mathrm{S}\left(\mathrm{CH}_{3}\right)\right.$; another isomer); $2.75\left(\mathrm{~s}, 3 \mathrm{H} ; \mathrm{S}\left(\mathrm{CH}_{3}\right)\right.$, one isomer); 2.66 (s, 3H; $\mathrm{S}\left(\mathrm{CH}_{3}\right)$, another isomer). TOF MS (ESI+): most abundant ion found for $[\mathrm{M}+\mathrm{Na}]^{+}, m / z$ 575.9. Calc. for $\mathrm{Ru}\left[\mathrm{C}_{16} \mathrm{H}_{19} \mathrm{Cl}_{2} \mathrm{~N}_{3} \mathrm{NaO}_{4} \mathrm{~S}_{2}\right]^{+}, m / z$ 575.91.

\section{$\left[\mathbf{R u}\left(\right.\right.$ phen' $\left.\left.^{\prime}\right)\left(\mathbf{b b}_{7}\right)\right]\left(\mathbf{P F}_{6}\right)_{2}$}

A solution of cis,cis-[RuCl $2(\mathrm{DMSO})_{2}\left(\right.$ phen' $\left.\left.^{\prime}\right)\right]$ \{where phen' $=$ phen; $\mathrm{Me}_{2}$ phen; $\mathrm{Me}_{4}$ phen; and $5-\mathrm{NO}_{2}$ phen $\}(0.39 \mathrm{mmol})$ and the $\mathrm{bb}_{7}$ ligand $(0.47 \mathrm{mmol})$ in $\mathrm{N}_{2}$-purged ethylene glycol (35 mL) was heated to $130-140{ }^{\circ} \mathrm{C}$ and stirred in an $\mathrm{N}_{2}$ atmosphere for $2 \mathrm{~h}$. The reaction mixture turned from light green to bright orange during the course of the reaction. The reaction mixture was cooled to room temperature and water $(10 \mathrm{~mL})$ was added to the bright-orange solution, which was then loaded onto a SP Sephadex C-25 cation-exchange column $(3 \times$ $20 \mathrm{~cm}$ ). The column was washed with water and the desired mononuclear complex was eluted with aqueous $\mathrm{NaCl}$ solution (0.3 M). Solid $\mathrm{KPF}_{6}(c a .5 \mathrm{mg}$ ) was added to the eluate and the complex was extracted into DCM $(2 \times 30 \mathrm{~mL})$. The organic layer was washed with water $(20 \mathrm{~mL})$, dried over anhydrous $\mathrm{Na}_{2} \mathrm{SO}_{4}$ and evaporated to dryness to obtain the $\mathrm{PF}_{6}{ }^{-}$salt of the complex. The complex was further purified by recrystallisation from acetonitrile/diethyl ether to obtain a bright-red/orange solid of $\left[\mathrm{Ru}\left(\mathrm{phen}^{\prime}\right)\left(\mathrm{bb}_{n}\right)\right]\left(\mathrm{PF}_{6}\right)_{2}$. Typical yields were approximately 20-25\%. For cis-[RuCl${ }_{2}(\mathrm{DMSO})_{2}\left(\mathrm{Me}_{2}\right.$ phen $\left.)\left(\mathrm{bb}_{7}\right)\right]\left(\mathrm{PF}_{6}\right)_{2}$ and cis $\left[\mathrm{RuCl}_{2}(\mathrm{DMSO})_{2}\left(\mathrm{Me}_{4}\right.\right.$-phen $\left.)\left(\mathrm{bb}_{7}\right)\right]\left(\mathrm{PF}_{6}\right)_{2}$, after recrystallisation, the symmetrical isomers were purified by the long SP Sephadex C-25 cation-exchange column $(1.5 \times 90 \mathrm{~cm})$.

\section{Purification of $c i s-\alpha$ isomers}

$\left[\mathrm{RuCl}_{2}(\mathrm{DMSO})_{2}\left(\mathrm{Me}_{2}\right.\right.$ phen $\left.)\left(\mathrm{bb}_{7}\right)\right]$ or $\quad\left[\mathrm{RuCl}_{2}(\mathrm{DMSO})_{2}\left(\mathrm{Me}_{4}\right.\right.$ phen $)$ $\left.\left(\mathrm{bb}_{7}\right)\right]\left(\mathrm{PF}_{6}\right)_{2}(35 \mathrm{mg})$ was converted into the chloride salt by stirring in methanol with Amberlite IRA-402 (chloride form) anion-exchange resin for $1 \mathrm{~h}$. After removal of the resin by fil- tration, the methanol filtrate was evaporated and the resultant chloride salt was dissolved in water $(20 \mathrm{~mL})$ and loaded onto a SP Sephadex C-25 cation-exchange column $(1.5 \times 90 \mathrm{~cm})$. The cis- $\alpha$ isomers and impurities were eluted as separate bands with an aqueous solution of sodium toluene-4-sulfonate $(0.125 \mathrm{M})$ as the eluent. Solid $\mathrm{KPF}_{6}$ was added to the eluents and the complexes were extracted into DCM $(2 \times 20 \mathrm{~mL})$. The organic layer was washed with water $(20 \mathrm{~mL})$, dried over anhydrous $\mathrm{Na}_{2} \mathrm{SO}_{4}$, and evaporated to dryness to obtain the $\mathrm{PF}_{6}$ salt of the complex.

cis- $\alpha-\left[\mathbf{R u}(\mathbf{p h e n})\left(\mathbf{b b}_{7}\right)\right]\left(\mathbf{P F}_{\mathbf{6}}\right)_{\mathbf{2}} \cdot \mathbf{C H}_{\mathbf{2}} \mathbf{C l}_{\mathbf{2}}$. Anal. calcd for $\mathrm{C}_{42} \mathrm{H}_{42} \mathrm{Cl}_{2} \mathrm{~F}_{12} \mathrm{~N}_{6} \mathrm{P}_{2} \mathrm{Ru}: \mathrm{C}, 46.2 \%$; $\mathrm{H}, 3.87 \%$; N, 7.7\%. Found: $\mathrm{C}$, $46.3 \%$; H, 3.90\%; N, 7.6\%. ${ }^{1} \mathrm{H}$ NMR (400 MHz, $\mathrm{CD}_{3} \mathrm{CN}$ ): $\delta 8.66$ (dd, $J=1.2,8.4 \mathrm{~Hz}, 2 \mathrm{H}$; H2/H9); 8.63 (dd, $J=1.2,5.2 \mathrm{~Hz}, 2 \mathrm{H}$; H4/H7); 8.32 (s, 2H; H5/H6); 8.28 (br s, 2H; bipy3); 8.15 (d, J = $1.2 \mathrm{~Hz}, 2 \mathrm{H}$, bipy3'); 7.74 (dd, $J=5.2,8.0 \mathrm{~Hz}, 2 \mathrm{H}, \mathrm{H} 3 / \mathrm{H} 8$ ); 7.47 (d, $J=6 \mathrm{~Hz}, 2 \mathrm{H}$; bipy6'); 7.16(d, $J=5.6 \mathrm{~Hz}, 2 \mathrm{H}$; bipy6); 7.08 (dd, $J=2.0,6.0 \mathrm{~Hz}, 2 \mathrm{H}$; bipy5'); 7.00 (dd, $J=1.2,6.0 \mathrm{~Hz}, 2 \mathrm{H}$; bipy5); 2.77-2.83 (m, 2H; $\mathrm{CH}_{2}$, bipy); 2.60-2.67 (m, 2H; $\mathrm{CH}_{2}$, bipy); 2.48 (s, 6H; $\mathrm{CH}_{3}$ bipy); 1.58-1.69 (m, 2H; $\mathrm{CH}_{2}$, bipy); 1.37-1.47 (m, 2H; $\mathrm{CH}_{2}$, bipy); 0.91-0.97 (m, 2H; $\mathrm{CH}_{2}$, bipy); 0.66-0.83 (m, $4 \mathrm{H} ; 2 \times \mathrm{CH}_{2}$, bipy). TOF MS (ESI+): most abundant ion found for $\left[\mathrm{M}-2 \mathrm{PF}_{6}\right]^{2+}, m / z$ 359.12. Calc. for $\mathrm{Ru}\left[\mathrm{C}_{41} \mathrm{H}_{40} \mathrm{~N}_{6}\right]^{2+}, m / z$ 359.12; most abundant ion found for $\left([\mathrm{M}-\mathrm{PF} 6]^{+}\right), \mathrm{m} / z$ 863.20. Calc. for $\mathrm{Ru}\left[\mathrm{C}_{41} \mathrm{H}_{40} \mathrm{~N}_{6}\left(\mathrm{PF}_{6}\right)\right]^{+}, m / z$ 863.21.

cis- $\alpha-\left[\mathbf{R u}\left(\mathbf{M e}_{2} \mathbf{p h e n}\right)\left(\mathbf{b b}_{7}\right)\right]\left(\mathbf{P F}_{\mathbf{6}}\right)_{2}$. Anal. calcd for $\mathrm{C}_{43} \mathrm{H}_{44} \mathrm{~F}_{12} \mathrm{~N}_{6} \mathrm{P}_{2} \mathrm{Ru}: \mathrm{C}, 49.9 \% ; \mathrm{H}, 4.28 \% ; \mathrm{N}, 8.1 \%$. Found: $\mathrm{C}$, $49.4 \%$; H, 4.37\%; N, 8.1\%. ${ }^{1} \mathrm{H}$ NMR (400 MHz, $\mathrm{CD}_{3} \mathrm{CN}$ ): $\delta 8.45$ (t, $J=5.6 \mathrm{~Hz}, 4 \mathrm{H} ; \mathrm{H} 2 / \mathrm{H} 9$ \& H5/H6); 8.27 (br s, 2H; bipy3); 8.13 (d, $J=1.2 \mathrm{~Hz}, 2 \mathrm{H}$, bipy3'); 7.57 (dd, $J=5.6,0.8 \mathrm{~Hz}, 2 \mathrm{H}, \mathrm{H} 3 / \mathrm{H} 8$ ); 7.46 (d, $J=5.6 \mathrm{~Hz}, 2 \mathrm{H}$; bipy6'); 7.16 (d, $J=5.6 \mathrm{~Hz}, 2 \mathrm{H}$; bipy6); 7.06 (dd, $J=1.6,5.6 \mathrm{~Hz}, 2 \mathrm{H}$; bipy5'); 7.00 (dd, $J=1.2,6.0 \mathrm{~Hz}$, 2H; bipy5); 2.95 (s, 6H; $\mathrm{CH}_{3} \mathrm{Me}_{2}$ phen); 2.76-2.82 (m, 2H; $\mathrm{CH}_{2}$, bipy); 2.60-2.66 (m, 2H; $\mathrm{CH}_{2}$, bipy); 2.47 (s, 6H; $\mathrm{CH}_{3}$ bipy); 1.60-1.68 (m, 2H; $\mathrm{CH}_{2}$, bipy); 1.37-1.46 (m, 2H; $\mathrm{CH}_{2}$, bipy); 0.90-0.97 (m, 2H; $\mathrm{CH}_{2}$, bipy); 0.63-0.82 (m, 4H; $2 \times \mathrm{CH}_{2}$, bipy). TOF MS (ESI+): most abundant ion found for $\left[\mathrm{M}-2 \mathrm{PF}_{6}\right]^{2+}, \mathrm{m} / \mathrm{z}$ 373.2. Calc. for $\mathrm{Ru}\left[\mathrm{C}_{43} \mathrm{H}_{44} \mathrm{~N}_{6} \mathrm{Ru}\right]^{2+}, m / z$ 373.0. Most abundant ion found for $\left(\left[\mathrm{M}-\mathrm{PF}_{6}\right]^{+}\right), \quad m / z$ 891.30. Calc. for $\mathrm{Ru}\left[\mathrm{C}_{43} \mathrm{H}_{44} \mathrm{~N}_{6}\left(\mathrm{PF}_{6}\right)\right]^{+}, m / z 890.88$.

cis- $\alpha-\left[\mathbf{R u}\left(\mathbf{M e}_{4}\right.\right.$ phen $\left.)\left(\mathbf{b b}_{7}\right)\right]\left(\mathbf{P F}_{6}\right)_{2} \cdot \mathbf{C H}_{2} \mathbf{C l}_{2}$. Anal. calcd for $\mathrm{C}_{46} \mathrm{H}_{50} \mathrm{Cl}_{2} \mathrm{~F}_{12} \mathrm{~N}_{6} \mathrm{P}_{2} \mathrm{Ru}: \mathrm{C}, 48.1 \% ; \mathrm{H}, 4.39 \%$;, $7.3 \%$. Found: $\mathrm{C}$, $48.2 \%$; H, 4.44\%; N, 7.7\%. ${ }^{1} \mathrm{H}$ NMR (400 MHz, $\mathrm{CD}_{3} \mathrm{CN}$ ): $\delta 8.43$ (s, 2H; H2/H9); 8.32 (s, 2H, H5/H6); 8.27 (s, 2H; bipy3); 8.13 (s, 2H, bipy3'); 7.45 (d, $J=6.0 \mathrm{~Hz}, 2 \mathrm{H}$; bipy6'); 7.16 (d, $J=5.6 \mathrm{~Hz}$, 2H; bipy6); 7.06 (dd, $J=1.6,4.4 \mathrm{~Hz}, 2 \mathrm{H}$; bipy5'); 7.00 (dd, $J=$ 0.8, $5.2 \mathrm{~Hz}, 2 \mathrm{H}$; bipy5); 2.83 (s, 6H, $\mathrm{CH}_{3} \mathrm{Me}_{4}$ phen); 2.77-2.79 (m, 2H; $\mathrm{CH}_{2}$, bipy); 2.60-2.66 (m, 2H; $\mathrm{CH}_{2}$, bipy); 2.48 (s, 6H; $\mathrm{CH}_{3}$ bipy); 2.36 (s, 6H, $\mathrm{CH}_{3} \mathrm{Me}_{4}$ phen); 1.60-1.69 (m, 2H; $\mathrm{CH}_{2}$, bipy); 1.38-1.47 (m, 2H; $\mathrm{CH}_{2}$, bipy); 0.92-0.98 (m, 2H; $\mathrm{CH}_{2}$, bipy); $0.67-0.83$ (m, 4H; $2 \times \mathrm{CH}_{2}$, bipy). TOF MS (ESI+): most abundant ion found for $\left[\mathrm{M}-2 \mathrm{PF}_{6}\right]^{2+}, \mathrm{m} / \mathrm{z}$ 387.2. Calc. for $\mathrm{Ru}\left[\mathrm{C}_{45} \mathrm{H}_{48} \mathrm{~N}_{6} \mathrm{Ru}\right]^{2+}, m / z$ 387.1. Most abundant ion found for $\left[\mathrm{M}-\mathrm{PF}_{6}\right]^{2+}, m / z$ 919.3. Calc for $\mathrm{Ru}\left[\mathrm{C}_{45} \mathrm{H}_{48} \mathrm{~N}_{6}\left(\mathrm{PF}_{6}\right)\right]^{+}, m / z$ 919.3.

cis- $\alpha-\left[\mathbf{R u}\left(\mathbf{5}-\mathrm{NO}_{2}\right.\right.$ phen $\left.)\left(\mathbf{b b}_{7}\right)\right]\left(\mathbf{P F}_{6}\right)_{2} \cdot \mathbf{1 . 5} \mathbf{C H}_{2} \mathbf{C l}_{2}$. Anal. calcd for $\mathrm{C}_{41.5} \mathrm{H}_{44} \mathrm{Cl}_{3} \mathrm{~F}_{12} \mathrm{~N}_{7} \mathrm{O}_{2} \mathrm{P}_{2} \mathrm{Ru}$ : C, 43.3\%; H, 3.59\%; N, 8.3\%. Found: 
$\mathrm{C}, 43.2 \%$; H, 3.61\%; N, 8.5\%. ${ }^{1} \mathrm{H}$ NMR (400 $\left.\mathrm{MHz}, \mathrm{CD}_{3} \mathrm{CN}\right)$ : $\delta 9.22$ (s, 1H, H6); 9.13 (d, $J=8.4 \mathrm{~Hz}, 2 \mathrm{H} ; \mathrm{H} 2) ; 8.80$ (dd, $J=3.2$, $8.4 \mathrm{~Hz}, 2 \mathrm{H}$; H4/H7); 8.75 (d, $J=5.6 \mathrm{~Hz}, 1 \mathrm{H}, \mathrm{H} 9) ; 8.29$ (s, 2H; bipy3'); 8.15 (s, 2H, bipy3); 7.62-7.88 (m, 2H, H3/H8); 7.45 (d, $J=6.0 \mathrm{~Hz}, 2 \mathrm{H}$; bipy6'); 7.19 (d, $J=5.6 \mathrm{~Hz}, 2 \mathrm{H}$; bipy6); 7.10 (dd, $J=1.6,5.6 \mathrm{~Hz}, 2 \mathrm{H}$; bipy5'); 7.03 (d, $J=6.0 \mathrm{~Hz}, 2 \mathrm{H}$; bipy5); 2.77-2.83 (m, 2H; $\mathrm{CH}_{2}$, bipy); 2.62-2.67 (m, 2H; $\mathrm{CH}_{2}$, bipy); 2.49 (s, 6H; $\mathrm{CH}_{3}$ bipy); 1.60-1.67 (m, 2H; $\mathrm{CH}_{2}$, bipy); 1.41-1.45 (m, 2H; $\mathrm{CH}_{2}$, bipy); 0.91-0.96 (m, 2H; $\mathrm{CH}_{2}$, bipy); 0.72-0.79 (m, $4 \mathrm{H} ; 2 \times \mathrm{CH}_{2}$, bipy). TOF MS (ESI+): +: most abundant ion found for $\left[\mathrm{M}-2 \mathrm{PF}_{6}\right]^{2+}, m / z$ 381.60. Calc. for $\mathrm{Ru}\left[\mathrm{C}_{41} \mathrm{H}_{39} \mathrm{~N}_{7} \mathrm{O}_{2}\right]^{2+}, m / z$ 381.61. Most abundant ion found for $\left[\mathrm{M}-\mathrm{PF}_{6}\right]^{+}, m / z$ 908.20. Calc. for $\mathrm{Ru}\left[\mathrm{C}_{41} \mathrm{H}_{39} \mathrm{~N}_{7} \mathrm{O}_{2}\left(\mathrm{PF}_{6}\right)\right], m / z$ 908.16.

\section{Density functional theory calculations}

The geometries of five ruthenium metal complexes - cis- $\alpha$ - and cis- $\beta-\left[\mathrm{Ru}\left(\mathrm{Me}_{4} \text { phen }\right)\left(\mathrm{bb}_{n}\right)\right]^{2+}(n=7$ and 12$)$ and $\left[\mathrm{Ru}\left(\mathrm{Me}_{2} \mathrm{bpy}\right)_{2}\right.$ $\left(\mathrm{Me}_{4}\right.$ phen $\left.)\right]^{2+}$ - were optimised with density functional theory (DFT) using QCHEM $4.4^{34}$ at the B3LYP/6-311G(d,p) ${ }^{35,36}$ level of theory with the LANL2DZ effective core potential ${ }^{37}$ used for ruthenium atoms. Calculations were carried out for both lowand high-spin electronic configurations of the complexes, with the low-spin state (multiplicity 1 and net charge 2) found to have the lower energy in all five cases, as expected for $\mathrm{d}^{6}$ octahedral ruthenium complexes. Initial structures for $c i s-\alpha-\left[\mathrm{Ru}\left(\mathrm{Me}_{4} \mathrm{phen}\right)-\right.$ $\left.\left(\mathrm{bb}_{7}\right)\right]^{2+}$ and $\left[\mathrm{Ru}\left(\mathrm{Me}_{2} \mathrm{bpy}\right)_{2}\left(\mathrm{Me}_{4} \text { phen }\right)\right]^{2+}$ were obtained from crystal structures and were used to build the initial structures for $c i s-\alpha-\left[\mathrm{Ru}\left(\mathrm{Me}_{4} \text { phen }\right)\left(\mathrm{bb}_{12}\right)\right]^{2+}$, cis- $\beta-\left[\mathrm{Ru}\left(\mathrm{Me}_{4} \mathrm{phen}\right)\left(\mathrm{bb}_{7}\right)\right]^{2+}$ and cis- $\beta-\left[\mathrm{Ru}\left(\mathrm{Me}_{4} \mathrm{phen}\right)\left(\mathrm{bb}_{12}\right)\right]^{2+}$ using Materials Studio 5.0. ${ }^{38}$

\section{Single crystal X-ray diffraction}

Crystals of compounds $\left[\mathrm{Ru}\left(\mathrm{Me}_{4}\right.\right.$ phen $\left.)\left(\mathrm{bb}_{7}\right)\right]\left(\mathrm{PF}_{6}\right)_{2} \cdot 3 \mathrm{CHCl}_{3}$ and $\left[\mathrm{Ru}\left(\mathrm{Me}_{4}\right.\right.$ phen $\left.)\left(\mathrm{Me}_{2} \mathrm{bpy}\right)_{2}\right]\left(\mathrm{PF}_{6}\right)_{2}$ suitable for X-ray crystallographic studies were grown by slow diffusion of toluene into a chloroform solution of $\left[\mathrm{Ru}\left(\mathrm{Me}_{4}\right.\right.$ phen $\left.)\left(\mathrm{bb}_{7}\right)\right]\left(\mathrm{PF}_{6}\right)_{2}$, and hexane into a DCM solution of $\left[\mathrm{Ru}\left(\mathrm{Me}_{4}\right.\right.$ phen $\left.)\left(\mathrm{Me}_{2} \mathrm{bpy}\right)_{2}\right]\left(\mathrm{PF}_{6}\right)_{2}$, respectively. $\left[\mathrm{Ru}\left(\mathrm{Me}_{4}\right.\right.$ phen $\left.)\left(\mathrm{bb}_{7}\right)\right]\left(\mathrm{PF}_{6}\right)_{2} \cdot 3 \mathrm{CHCl}_{3}$ crystallised as orange rod-shaped crystals and $\left[\mathrm{Ru}\left(\mathrm{Me}_{4}\right.\right.$ phen $\left.)\left(\mathrm{Me}_{2} \mathrm{bpy}\right)_{2}\right]\left(\mathrm{PF}_{6}\right)_{2}$ as orange plate-like crystals. Single crystals were selected and mounted on a nylon loop in paratone- $\mathrm{N}$ cryo-protectant. Single-crystal X-ray diffraction was performed at 100(2) K on the $\mathrm{MX}-1$ beamline of the Australian Synchrotron $(\lambda=$ $0.7107 \AA) .{ }^{39}$ Data sets were corrected for absorption using a multi-scan method, and structures were solved by direct methods using SHELXS-2014 and refined by full-matrix least squares on $F^{2}$ by SHELXL-2014, ${ }^{40}$ interfaced through the program X-Seed. ${ }^{41}$ In general, all non-hydrogen atoms were refined anisotropically and hydrogen atoms were included as invariants at geometrically estimated positions, unless specified otherwise.

CIF data have been deposited with the Cambridge Crystallographic Data Centre, CCDC reference numbers 1559396 and $1558934 \dagger$ \{where $\left[\mathrm{Ru}\left(\mathrm{Me}_{4} \mathrm{phen}\right)\left(\mathrm{bb}_{7}\right)\right]\left(\mathrm{PF}_{6}\right)_{2} \cdot 3 \mathrm{CHCl}_{3}=$ 1559396 and $\left[\mathrm{Ru}\left(\mathrm{Me}_{4}\right.\right.$ phen $\left.\left.)\left(\mathrm{Me}_{2} \mathrm{bpy}\right)_{2}\right]\left(\mathrm{PF}_{6}\right)_{2}=1558934\right\}$.

\section{Special refinement details}

Compound $\left[\mathrm{Ru}\left(\mathrm{Me}_{4}\right.\right.$ phen $\left.)\left(\mathrm{bb}_{7}\right)\right]\left(\mathrm{PF}_{6}\right)_{2}$ crystallises with three molecules of chloroform in the unit cell, two of which are disordered over 2 positions. The disorder was modelled and both molecules were left to freely refine to give $70 \%$ and $76 \%$ occupancy for each main position.

\section{Bacterial strains}

Two Staphylococcus aureus (Gram-positive) isolates \{a wild type $S$. aureus strain (SH 1000) and a clinical multidrug-resistant MRSA strain (USA 300 LAC JE2)\}, and three Gram-negative Escherichia coli isolates \{MG 1655, NCTC 12241 (APEC) and ST 131 (UPEC) $\}$ and a Pseudomonas aeruginosa strain PAO1 (WT), were used for in vitro antimicrobial studies.

\section{MIC and MBC determination}

The MIC tests were conducted by the broth micro-dilution method in duplicate as outlined in the CLSI guidelines. ${ }^{42}$ The MBC tests were performed in duplicate according to the standard microbiological techniques protocol. ${ }^{43}$ The bacteria were grown in LB media incubating at $37{ }^{\circ} \mathrm{C}$ for overnight. After washing and suspending in CAMHB, the bacteria were plated out on Mueller-Hinton agar, grown overnight and then suspended in growth medium CAMHB. Bacterial inocula were adjusted to a turbidity equivalent to that of a 0.5 McFarland standard and diluted to a final concentration of $4-8 \times 10^{5}$ cfu $\mathrm{mL}^{-1}$. Compounds tested were dissolved and serially diluted in CAMHB in sterile 96-well flat-bottom plates to a final volume of $100 \mu \mathrm{L}$ in each well. An equal volume of inocula was added to each well, making a final concentration range of the compounds tested, including the control antibiotics gentamicin, of between 0.25 and $128 \mu \mathrm{g} \mathrm{mL}^{-1}$. MICs were recorded after $16-18 \mathrm{~h}$ of incubation at $37^{\circ} \mathrm{C}$. Colony counts of the inocula were performed for determination of the MBC. After MIC results were noted, $10 \mu \mathrm{L}$ from each well was plated out on Mueller-Hinton agar. MBCs were recorded after overnight incubation at $37^{\circ} \mathrm{C}$, and the concentration of compounds that produced a $99.9 \%$ kill relative to the starting inoculum was recorded as the MBC.

\section{Cellular accumulation}

The cellular accumulation of the ruthenium complexes was measured by monitoring the luminescence of the complexes remaining in the supernatant of the cultures after incubation for various periods. Bacterial inocula in log phase were adjusted to a cell concentration from $1-7 \times 10^{7} \mathrm{cfu} \mathrm{mL}^{-1}$. The cell culture $(24 \mathrm{~mL})$ was placed in a $250 \mathrm{~mL}$ conical flask and $75 \mu \mathrm{L}$ of stock solution $\left(2.56 \mathrm{mg} \mathrm{mL}^{-1}\right)$ of the ruthenium complex was added to give a final concentration of $8 \mu \mathrm{g} \mathrm{mL} \mathrm{m}^{-1}$. Control flasks containing $50 \mathrm{~mL}$ of each bacterial suspension were set up as blank samples to obtain fluorescence calibration curves for each complex. Culture flasks and control flasks were incubated with shaking (Incu-shake TL6-5, SciQuip Ltd, Newtown, Wem, Shropshire, UK) at $200 \mathrm{rpm}$ at $37^{\circ} \mathrm{C}$ for 15, 30, 60, 90 or $120 \mathrm{~min}$. At each time point, $3.3 \mathrm{~mL}$ of 
bacterial suspension was centrifuged $(5500 \mathrm{rpm})$ at $4{ }^{\circ} \mathrm{C}$ for $10 \mathrm{~min}$. Supernatants $(3 \mathrm{~mL})$ were carefully transferred to $5 \mathrm{~mL}$ tubes and the phosphorescence of the remaining ruthenium complex was measured on a Cary Eclipse Fluorescence Spectrophotometer with $\lambda_{\mathrm{ex}}=488 \mathrm{~nm}$. The emission spectra were collected from $\lambda=500-800 \mathrm{~nm}$. Volumes $(21,39,57$, 75 and $93 \mu \mathrm{L})$ of a stock solution $\left(320 \mu \mathrm{g} \mathrm{mL} \mathrm{m}^{-1}\right)$ of each complex were added to $3 \mathrm{~mL}$ aliquots of the supernatant from each control bacterial suspension (untreated with drug) to acquire a fluorescence-concentration linear correlation chart for calibration.

\section{Lipophilicity $(\log P)$ determination}

The partition coefficients $(\log P$ ) were measured using the shake-flask technique. Each ruthenium complex (0.1 mM) was dissolved in the water phase (Milli-Q water) and an equal volume of $n$-octanol was added. The two phases were mutually saturated by shaking overnight at ambient temperature and allowed to separate on standing. The concentration of the metal complex in each phase was determined spectrophotometrically at $\lambda=450 \mathrm{~nm}$.

\section{DNA-binding studies}

Experiments were carried out in phosphate-buffered saline (PBS) at $\mathrm{pH}$ 7.4. The ratio of the UV absorbance of a solution of CT-DNA at $\lambda=260$ and $280 \mathrm{~nm}$ was greater than 1.8 , thus indicating that the CT-DNA was sufficiently free from protein. The DNA concentration of the stock solution $\left(2.8 \times 10^{-3} \mathrm{M}\right)$ was determined by UV absorbance by using a molar absorption coefficient of $13300 \mathrm{M}^{-1} \mathrm{~cm}^{-1}$ per base pair at $\lambda=$ $260 \mathrm{~nm}$. Absorption titration experiments were carried out by keeping the concentration of the ruthenium complex constant $\left(2 \times 10^{-5} \mathrm{M}\right)$ and varying the CT-DNA concentration from 0 to fully binding. Absorbance values were recorded after each successive addition of the solution of CT-DNA.

\section{Conflicts of interest}

There are no conflicts to declare.

\section{Acknowledgements}

BS is grateful for a UNSW Canberra PhD scholarship and a Travel Grant to carry out the microbiology experiments at Sheffield University. A. T. thanks CSIRO Materials Science and Engineering for a Ph.D. top-up scholarship. RKP thanks the UK Biotechnology and Biological Sciences Research Council (BBSRC) for grant BB/M022579/1. Aspects of this research were undertaken on the MX1 beamline at the Australian Synchrotron, Victoria, Australia. This research was undertaken with the assistance of resources from the National Computational Infrastructure (NCI), which is supported by the Australian Government.

\section{References}

1 http://www.who.int/mediacentre/factsheets/antibiotic-resistance/en/.

2 F. Li, J. G. Collins and F. R. Keene, Chem. Soc. Rev., 2015, 44, 2529.

3 H. M. Southam, J. A. Butler, J. A. Chapman and R. K. Poole, Adv. Microb. Physiol., 2017, 71, 1.

4 X. Li, A. K. Gorle, M. K. Sundaraneedi, F. R. Keene and J. G. Collins, Coord. Chem. Rev., 2018, DOI: 10.1016/ jccr2017.11.011.

5 A. D. Richards, A. Rodger, M. J. Hannon and A. Bolhuis, Int. J. Antimicrob. Agents, 2009, 33, 469.

6 N. S. Ng, P. Leverett, D. E. Hibbs, Q. Yang, J. C. Bulanadi, M. Jie Wu and J. R. Aldrich-Wright, Dalton Trans., 2013, 42, 3196.

7 M. A. Neelakantan, M. Esakkiammal, S. S. Mariappan, J. Dharmaraja and T. Jeyakumar, Indian J. Pharm. Sci., 2010, 72, 216.

8 F. P. Dwyer, E. C. Gyarfas, W. P. Rogers and J. H. Koch, Nature, 1952, 170, 190.

9 F. P. Dwyer, I. K. Reid, A. Shulman, G. M. Laycock and S. Dixson, Aust. J. Exp. Biol. Med. Sci., 1969, 47, 203.

10 A. Bolhuis, L. Hand, J. E. Marshall, A. D. Richards, A. Rodger and J. Aldrich-Wright, Eur. J. Pharm. Sci., 2011, 42, 313.

11 C. Shobha Devi, D. Anil Kumar, S. S. Singh, N. Gabra, N. Deepika, Y. P. Kumar and S. Satyanarayana, Eur. J. Med. Chem., 2013, 64, 410.

12 F. Li, Y. Mulyana, M. Feterl, J. M. Warner, J. G. Collins and F. R. Keene, Dalton Trans., 2011, 40, 5032.

13 M. Pandrala, F. Li, M. Feterl, Y. Mulyana, J. M. Warner, L. Wallace, F. R. Keene and J. G. Collins, Dalton Trans., 2013, 42, 4686.

14 A. K. Gorle, M. Feterl, J. M. Warner, L. Wallace, F. R. Keene and J. G. Collins, Dalton Trans., 2014, 43, 16713.

15 F. Li, M. Feterl, Y. Mulyana, J. M. Warner, J. G. Collins and F. R. Keene, J. Antimicrob. Chemother., 2012, 67, 2686.

16 A. K. Gorle, X. Li, S. Primrose, F. Li, M. Feterl, R. T. Kinobe, K. Heimann, J. M. Warner, F. R. Keene and J. G. Collins, J. Antimicrob. Chemother., 2016, 71, 1547.

17 A. K. Gorle, M. Feterl, J. M. Warner, S. Primrose, C. C. Constantinoiu, F. R. Keene and J. G. Collins, Chem. Eur. J., 2015, 21, 10472.

18 F. Li, E. J. Harry, A. L. Bottomley, M. D. Edstein, G. W. Birrell, C. E. Woodward, F. R. Keene and J. G. Collins, Chem. Sci., 2014, 5, 685.

19 X. Li, A. K. Gorle, T. D. Ainsworth, K. Heimann, C. E. Woodward, J. G. Collins and F. Richard Keene, Dalton Trans., 2015, 44, 3594.

20 R. B. Nair, E. S. Teng, S. L. Kirkland and C. J. Murphy, Inorg. Chem., 1998, 37, 139.

21 I. Haq, P. Lincoln, D. Suh, B. Norden, B. Z. Chowdhry and J. B. Chaires, J. Am. Chem. Soc., 1995, 117, 4788. 
22 A. Breivogel, S. Wooh, J. Dietrich, T. Y. Kim, Y. S. Kang, K. Char and K. Heinze, Eur. J. Inorg. Chem., 2014, 2014, 2720; and references therein.

23 G. Kalyuzhny, M. Buda, J. McNeill, P. Barbara and A. J. Bard, J. Am. Chem. Soc., 2003, 125, 6272.

24 B. S. Howerton, D. K. Heidary and E. C. Glazer, J. Am. Chem. Soc., 2012, 134, 8324.

25 T. Strateva and D. Yordanov, J. Med. Microbiol., 2009, 58, 1133.

26 F. Li, M. Feterl, J. M. Warner, F. R. Keene and J. G. Collins, J. Antimicrob. Chemother., 2013, 68, 2825.

27 S. V. Kumar, S. Ø. Scottwell, E. Waugh, C. J. McAdam, L. R. Hanton, H. J. L. Brooks and J. D. Crowley, Inorg. Chem., 2016, 55, 9767.

28 N. L. Kilah and E. Meggers, Aust. J. Chem., 2012, 65, 1325.

29 P.-L. Lam, G.-L. Lu, K.-M. Hon, K.-W. Lee, C.-L. Ho, X. Wang, J. C.-O. Tang, K.-H. Lam, R. S.-M. Wong, S. H.-L. Kok, Z.-X. Bian, H. Li, K. K.-H. Lee, R. Gambari, C.-H. Chui and W.-Y. Wong, Dalton Trans., 2014, 43, 3949.

30 Y. Mulyana, D. K. Weber, D. P. Buck, C. A. Motti, J. G. Collins and F. R. Keene, Dalton Trans., 2011, 40, 1510.

31 I. P. Evans, A. Spencer and G. Wilkinso, J. Chem. Soc., Dalton Trans., 1973, 204.

32 H. A. Hudali, J. V. Kingston and H. A. Tayim, Inorg. Chem., 1979, 18, 1391.
33 R. C. Van der Drift, J. W. Sprengers, E. Bouwman, W. P. Mul, H. Kooijman, A. L. Spek and E. Drent, Eur. J. Inorg. Chem., 2002, 2147.

34 Y. Shao, et al., Mol. Phys., 2015, 113, 184; full author list provided in ESI. $\dagger$

35 A. D. Becke, J. Chem. Phys., 1993, 98, 5648.

36 R. Krishnan, J. S. Binkley, R. Seeger and J. A. Pople, J. Chem. Phys., 1980, 72, 650.

37 P. J. Hay and W. R. Wadt, J. Chem. Phys., 1985, 82, 299.

38 Materials Studio 5.0, Accelrys Software Inc., San Diego, 2009.

39 T. M. McPhillips, S. E. McPhillips, H. J. Chiu, A. E. Cohen, A. M. Deacon, P. J. Ellis, E. Garman, A. Gonzalez, N. K. Sauter, R. P. Phizackerley, S. M. Soltis and P. Kuhn, J. Synchrotron Radiat., 2002, 9, 401.

40 (a) G. M. Sheldrick, Acta Crystallogr., Sect. A: Found. Crystallogr., 2008, 64, 112; (b) G. M. Sheldrick, Acta Crystallogr., Sect. C: Struct. Chem., 2015, 71, 3.

41 L. J. Barbour, J. Supramol. Chem., 2001, 1, 189.

42 Clinical and Laboratory Standards Institute, Performance Standards for Antimicrobial Susceptibility Testing: Nineteenth Informational Supplement M100-S19, CLSI, Wayne, PA, USA, 2009.

43 K. D. M. Motyl, J. Barrett and R. Giacobbe, Current Protocols in Pharmacology, John Wiley \& Sons, New York, 2005. 